\title{
Chalcidoidea (Hymenoptera) obtained from common reed, Phragmites australis (Cav.) Trin. ex Steud. (Poaceae) in Iran with new records and descriptions of two new species
}

\author{
Hossein LOTFALIZADEH ${ }^{1}$, Younes KARIMPOUR ${ }^{2, *}$, \\ Gérard DELVARE $^{3} \&$ Jean-Yves RASPLUS ${ }^{4}$ \\ ${ }^{1}$ Plant Protection Research Department, East-Azarbaijan Agricultural and Natural Resources Research \\ and Education Center, AREEO, Tabriz, Iran. \\ ${ }^{2}$ Department of Plant Protection, Faculty of Agriculture, Urmia University, Urmia, Iran. \\ ${ }^{3}$ CIRAD, UMR 1062 CBGP, Montferrier-sur-Lez, France. \\ ${ }^{4}$ CBGP, Univ. Montpellier, CIRAD, INRA, IRD, Montpellier SupAgro, Montpellier, France. \\ *Corresponding author: y.karimpour@urmia.ac.ir \\ 1Email: hlotfalizadeh@gmail.com \\ ${ }^{3}$ Email: gerard.delvare@cirad.fr \\ ${ }^{4}$ Email: Jean-Yves.Rasplus@inra.fr

\footnotetext{
${ }^{1}$ urn:1sid:zoobank.org:author:D7C681F3-C2E3-4FC1-BC4A-B0A6160B56CC

${ }^{2}$ urn:lsid:zoobank.org:author:E7B0992C-BBFA-444A-A694-D3F54FDA10B0

${ }^{3}$ urn:1sid:zoobank.org:author:5FF70B98-CC45-42DF-86ED-7A6CD33D16FB

${ }^{4}$ urn:1sid:zoobank.org:author:981D4685-5DA3-44AD-B056-CA5877F06329
}

\begin{abstract}
Fourteen species of Chalcidoidea (Encyrtidae, Eulophidae, Eupelmidae, Eurytomidae, Pteromalidae and Torymidae) were obtained from the common reed, Phragmites australis (Cav.) Trin. ex Steud. (Poaceae) in the Urmia region, in the northwest of Iran. Among these species, two new species of Pteromalidae are described hereafter: Norbanus persicus Lotfalizadeh \& Rasplus sp. nov. and Stenomalina delvarei Lotfalizadeh \& Rasplus sp. nov. Anagyrus near alienus Japoshvili, 2002, Asitus sp., Cheiloneurus paralia (Walker, 1837), Echthroplexiella obscura (Hoffer, 1952), Neococcidencyrtus poutiersi (Mercet, 1922) (all Encyrtidae), Aprostocetus orithyia (Walker, 1839) (Eulophidae), Eupelmus phragmitis Erdös, 1955 (Eupelmidae), Aximopsis deserticola (Zerova, 2004) comb. nov., Tetramesa phragmitis (Erdös, 1952) and Tetramesa sp. (all Eurytomidae), Homoporus febriculosus (Girault, 1917) (Pteromalidae) and Torymus arundinis (Walker, 1833) (Torymidae) were also obtained from our laboratory rearing. Nine of these species are recorded for the first time from Iran.
\end{abstract}

Keywords. Encyrtidae, Eulophidae, Eupelmidae, Pteromalidae, Eurytomidae, Norbanus, Stenomalina, Torymidae, new species, new record.

Lotfalizadeh H., Karimpour Y., Delvare G. \& Rasplus J.-Y. 2020. Chalcidoidea (Hymenoptera) obtained from common reed, Phragmites australis (Cav.) Trin. ex Steud. (Poaceae) in Iran with new records and descriptions of two new species. European Journal of Taxonomy 710: 1-35. https://doi.org/10.5852/ejt.2020.710 


\section{Introduction}

The genus Phragmites Adans. (Poales, Poaceae) comprises the most common species of grasses (Poonawala et al. 1999). These monocot species are perennial, rhizomatous, stoloniferous and relatively tall (2.0-6.0 m). Among them, the common reed, Phragmites australis (Cav.) Trin. ex Steud., known as "Nei" in Persian, is a clonal and sub-cosmopolitan species (Clevering \& Lissner 1999) and extremely abundant in the temperate regions (Haslam 1972). It is an invasive plant in some parts of its distribution, and there is a considerable body of scientific knowledge on its biology and ecology (Mal \& Narine 2004; Kiviat 2013; Srivastava et al. 2013). Over the world, P. australis is known to host a huge diversity of insect species and at least 140 herbivorous species are associated with the common reed in Europe (Schwarzländer \& Häfliger 1999; Tscharntke, 1999; Tewksbury et al. 2002), causing significant damage. Among these insect species, more than 70\%, attack the leaves and the stems (Tewksbury et al. 2002). Schwarzländer \& Häfliger (1999) revealed that $50 \%$ of these phytophagous species are specialists, associated only with the genus Phragmites. Tewksbury et al. (2002) considered that $40 \%$ of the species associated with Phragmites are monophagous, and that Diptera Linnaeus, 1758 (with 55 species) and Lepidoptera Linnaeus, 1758 (with 45 species) are the two most represented insect orders. Several phytophagous species associated with Phragmites are rhizome-feeders, e.g., lepidopterous and some others stem-borers, e.g., moths and chloropid flies (Barczak et al. 2013). These phytophagous insects have been investigated for their efficiency in controlling of $P$. australis in North America (Tewksbury et al., 2002) and at least two species of European noctuid moths viz., Archanara geminipuncta Haworth, 1809 and A. neurica (Hübner, 1808) are being tested as potential biological control agents in North America.

However, little attention has been given to the numerous parasitic wasps that parasitize the phytophagous insects associated with Phragmites spp. Among them, Chalcidoidea Latreille, 1817 (Hymenoptera) is the most represented superfamily and about 152 species belonging to 10 families of chalcid wasps have been cited worldwide. About $39 \%$ of associated Chalcidoidea with Phragmites spp. (61 species from 9 families) have been reported with phytophagous insects on Phragmites australis (Table 1) (Noyes 2020). While most of the chalcid species are parasitoids, Tetramesa spp. (Hym.: Eurytomidae) are phytophagous.

The aim of this study was to investigate the parasitic community associated with some phytophagous insects developing in the common reed in Iran. Our study is a first step towards a more comprehensive survey and we here describe the diagnostic characters of these wasps for future bio-ecological studies.

\section{Material and methods}

Preliminary probes to find overwintered and attacked stems of common reed by splitting them had shown that stems with a maximum height of 50 to $120 \mathrm{~cm}$ were more infected than higher and flowered stems. Upon awareness of this, we started to collect the likely attacked samples of reed stems at several times during March-April of 2016. Samples were picked out from about $50 \mathrm{~cm}$ from the top of the stems whose maximum height was between 40 and $140 \mathrm{~cm}$. About 500 samples of reed stems were collected in nine dry/moist and dense /rare reed stands from four different sites on the edges of farmlands and abandoned areas in the Urmia region: Orümïyeh, Azarbaijan-e Gharbi (= West-Azarbaijan) Province, Iran. The sites and their geographical coordinates (Anonymous 2006) are given below:

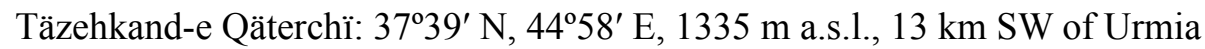

Kelïsä Kandï: $37^{\circ} 29^{\prime} \mathrm{N}, 45^{\circ} 01^{\prime} \mathrm{E}, 1600$ m a.s.1., $2.5 \mathrm{~km} \mathrm{SW}$ of Urmia

Häshtïan: $37^{\circ} 47^{\prime} \mathrm{N}, 44^{\circ} 39^{\prime} \mathrm{E}, 1680 \mathrm{~m}$ a.s.1., $50 \mathrm{~km}$ NW of Urmia

Hesar-e Türkmän: $37^{\circ} 26^{\prime} \mathrm{N}, 45^{\circ} 13^{\prime}$ E, 1293 m a.s.1., 15 km SE of Urmia 
Table 1. Number of chalcid genera and species reported from Phragmites australis (Cav.) Trin. ex Steud. (Noyes 2020).

\begin{tabular}{lcc}
\hline Family & Number of genera & Number of species \\
\hline Aphelinidae & 1 & 2 \\
Encyrtidae & 17 & 25 \\
Eulophidae & 4 & 13 \\
Eupelmidae & 2 & 4 \\
Eurytomidae & 2 & 4 \\
Mymaridae & 1 & 1 \\
Pteromalidae & 8 & 10 \\
Signiphoridae & 1 & 1 \\
Torymidae & 1 & 1 \\
\hline Total & $\mathbf{3 7}$ & $\mathbf{6 1}$ \\
\hline
\end{tabular}

According to the above mentioned area, we prepared four separate glass boxes $(30 \times 40 \times 80 \mathrm{~cm})$, covered by muslin for maintenance of reed stem samples and rearing of insects at the entomology laboratory of the Department of Plant Protection, Faculty of Agriculture, Urmia University.

The collected reed stems were brought to the laboratory. They were placed into the prepared boxes according to the related area, checked daily, and the emerging wasps and their likely hosts were collected with an aspirator. In order to collect the insects inside the boxes, we first moved them to the side of the window and then carefully removed part of the box's cover to collect the insects inside them with an aspirator. In cases where insects escaped from the box they were gathered next to the window glass, and subsequently also collected with an aspirator. The emerging dates of the specimens were recorded daily. Wasps were subsequently preserved in $75 \%$ ethanol before identification.

Collected specimens were air dried and card-mounted. Specimens were examined with a Leica M205C stereo microscope and a Leica CLS 150X fiber optic light source. Imaging was conducted using a Keyence VHX-5000 multiple-focus imaging system, and assemblage and edition were done with Adobe Photoshop $\mathrm{CS}^{\circ}{ }^{\circ}$ software.

The reared chalcidoids were identified using the keys of Ferrière (1955), Claridge (1958), Zerova (1976, 2010), Graham (1987), Noyes (1987), Bouček \& Rasplus (1991), Graham \& Gijswijt (1998), Trjapitzin (2006), Zerova \& Seryogina (2006), Rizzo \& Mitroiu (2010), Mitroiu (2015) and Gibson \& Fusu (2016).

The type material and all studied specimens are deposited in the HMIM (Hayk Mirzayans Insect Museum, Tehran, Iran) and in CBGP insect collection (Centre de Biologie pour la Gestion des Populations, Montferrier-sur-Lez, France). Identified families, genera and species were listed alphabetically.

\section{Abbreviations}

$\begin{array}{ll}\text { F1-F6 } & \text { funicular segments } 1-6 \\ \text { POL } & =\text { distance between posterior ocelli } \\ \text { OOL } & =\text { distance between posterior ocellus and the eye } \\ \text { GT1-GT6 } & =\text { gastral tergites } 1-6\end{array}$




\section{Results}

The survey for the collection and rearing of the chalcid wasp composition associated with common reeds in the Urmia region resulted in the identification of 203 specimens (162 + o+ and $41 \lesssim \delta$ ), pertaining to 14 species, 13 genera and 6 families: Encyrtidae Walker, 1837 (5 species), Eurytomidae Walker, 1832 (3), Torymidae Walker, 1833 (1), Eupelmidae Walker, 1833 (1), Eulophidae Westwood, 1829 (1) and Pteromalidae Dalman, 1820 (3). Of these, two species of Pteromalidae appeared to be new for science and are described hereafter. Nine species of chalcidoid wasps were sampled for the first time in Iran. Among them, two species, namely Tetramesa phragmitis Erdös, 1952 and Tetramesa sp., are phytophagous on common reed. Our rearing of the phytophagous insects associated with the common reed in Iran yielded several putative hosts of the bred chalcid wasps: Chloropidae Verrall, 1888 (3 species), Crambidae Latreille, 1810 (1), Cecidomyiidae Newman, 1835 (2), Mordellidae Latreille, 1802 (1), Agromyzidae Fallén, 1823 (1) and Pseudococcidae Heymons, 1915 (1).

Family Encyrtidae Walker, 1837

Subfamily Tetracneminae Howard, 1892

Genus Anagyrus Howard, 1896

Anagyrus near alienus Japoshvili, 2012

Fig. 1

\section{Material examined}

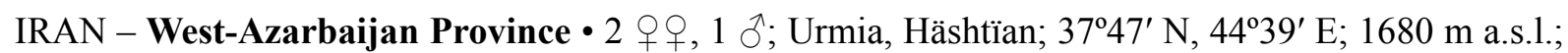

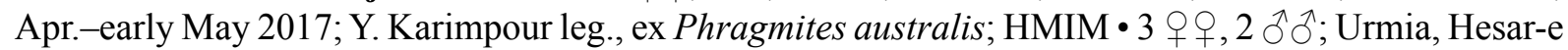
Türkmän; 37 $26^{\prime}$ N, 45 $5^{\circ} 3^{\prime}$ E; 1293 m a.s.l.; Apr. 2017; Y. Karimpour leg., ex Phragmites australis;

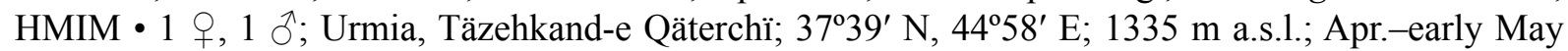
2017; Y. Karimpour leg., ex Phragmites australis; HMIM.

\section{Remarks}

Our specimens possess all the diagnostic characters of A. alienus, but the females are slightly larger $(2.2 \mathrm{~mm})$ than the type specimens of A. alienus $(1.7 \mathrm{~mm})$. Furthermore, the scape (Fig. 1B) is also slightly wider than in A. alienus (about $2.5 \times$ vs $3.3 \times$ as long as broad in A. alienus), consequently our specimens could represent an undescribed species. Anagyrus alienus was previously known from Turkey and our sampling locality is close to the type locality. The biology of A. alienus is unknown (Japoshvili 2012). Our sampling reveals an association of $A$. near alienus with $P$. australis, on which it is associated with a species of Pseudococcidae (Hemiptera) that appears to be a pest of $P$. australis.

\section{Genus Asitus Erdös 1955}

\section{Asitus sp.}

Fig. 2

\section{Material examined}

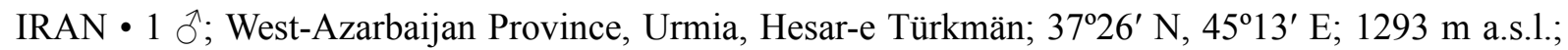
Apr. 2017; Y. Karimpour leg.; ex Phragmites australis; HMIM.

\section{Remarks}

Asitus phragmitis (Ferrière, 1955) is a parasitoid of Pseudococcidae on Phragmites australis in the Caucasus, several European countries, USA and Pakistan (Ferrière 1955; Guerrieri 1989; Noyes 2020). Our specimen is closely related to A. phragmitis and shares several characters with that species: body 


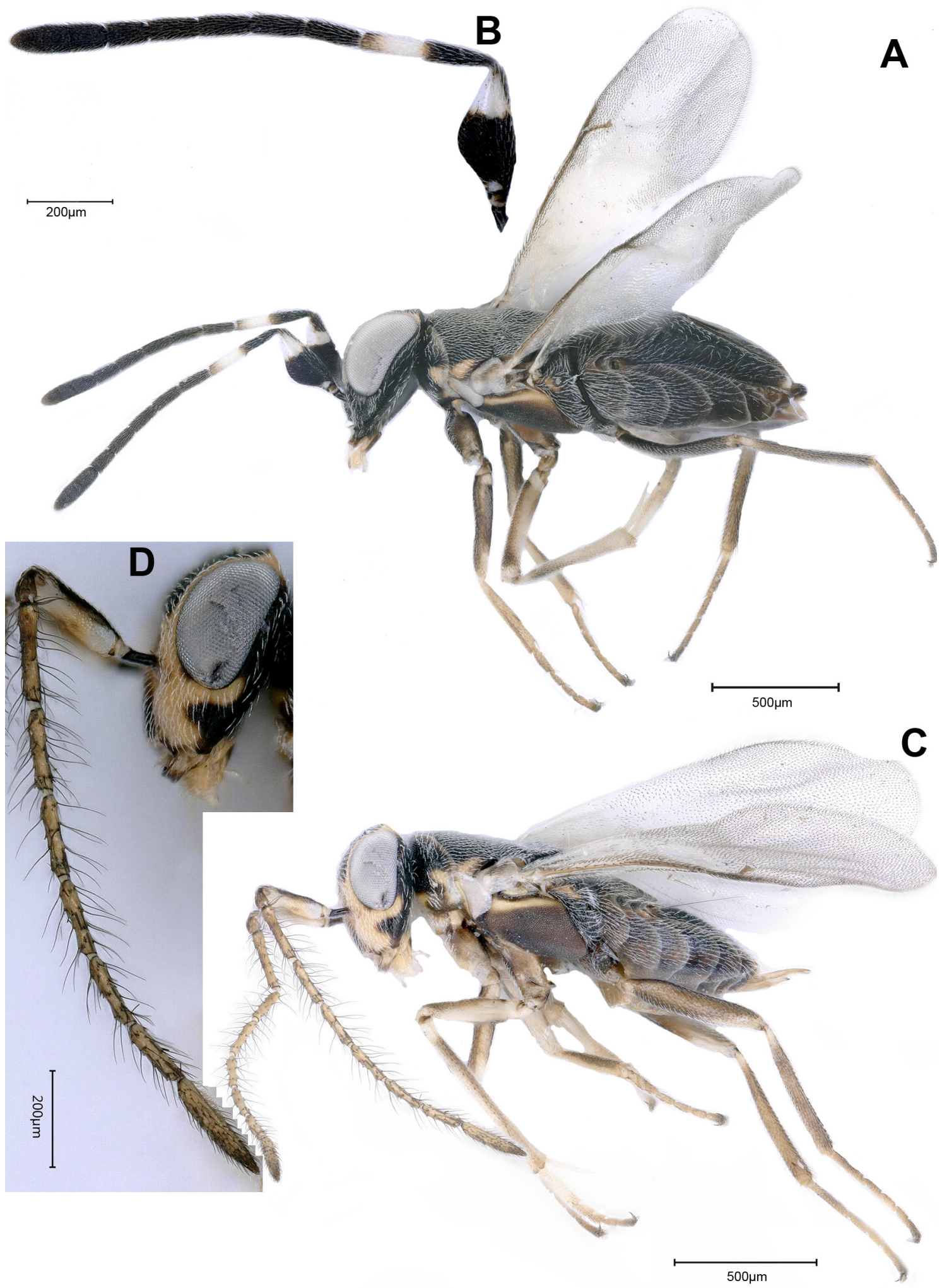

Fig. 1. Anagyrus near alienus Japoshvili, 2012. A. Female body in lateral view. B. Right antenna of female. C. Male body in lateral view. D. Left antenna of male. 
Table 2. Features distinguishing male Asitus sp. from A. phragmitis (Ferrière, 1955).

\begin{tabular}{|c|c|c|}
\hline Characters & Asitus sp. & $\begin{array}{c}\text { A. phragmitis } \\
\text { (from Guerrieri 1989) }\end{array}$ \\
\hline POL/ OOL & About $1.3 \times$ (Fig. 2B) & $1.5 \times$ \\
\hline Funicle & $\begin{array}{l}\text { Filiform, all funicular segments } \\
\text { longer than wide (Fig. 2C) }\end{array}$ & $\begin{array}{l}\text { Moniliform, at least F6 } \\
\text { transverse }\end{array}$ \\
\hline Clava & Long, about $5 \times$ as long as wide & Short, about $2 \times$ as long as wide \\
\hline Funicle + clava & About $1.2 \times$ as long as head width & $\begin{array}{l}\text { Slightly shorter than head width, } \\
\text { about } 0.9 \times\end{array}$ \\
\hline Pedicel & $\begin{array}{l}\text { Shorter than F1+F2, about } 0.8 \times \\
\text { (Fig. 2C) }\end{array}$ & As long as $\mathrm{F} 1+\mathrm{F} 2$ \\
\hline Metanotum and propodeum & Reticulate (Fig. 2B) & Smooth \\
\hline Fore wing fringe & $\begin{array}{l}\text { Shorter on frontal margin than on } \\
\text { dorsal margin, about } 0.5 \times \\
\text { (Fig. 2A) }\end{array}$ & $\begin{array}{l}\text { Same length on frontal and } \\
\text { dorsal margins }\end{array}$ \\
\hline Marginal vein & Long, $2 \times$ as long as wide & Short, about as long as wide \\
\hline
\end{tabular}

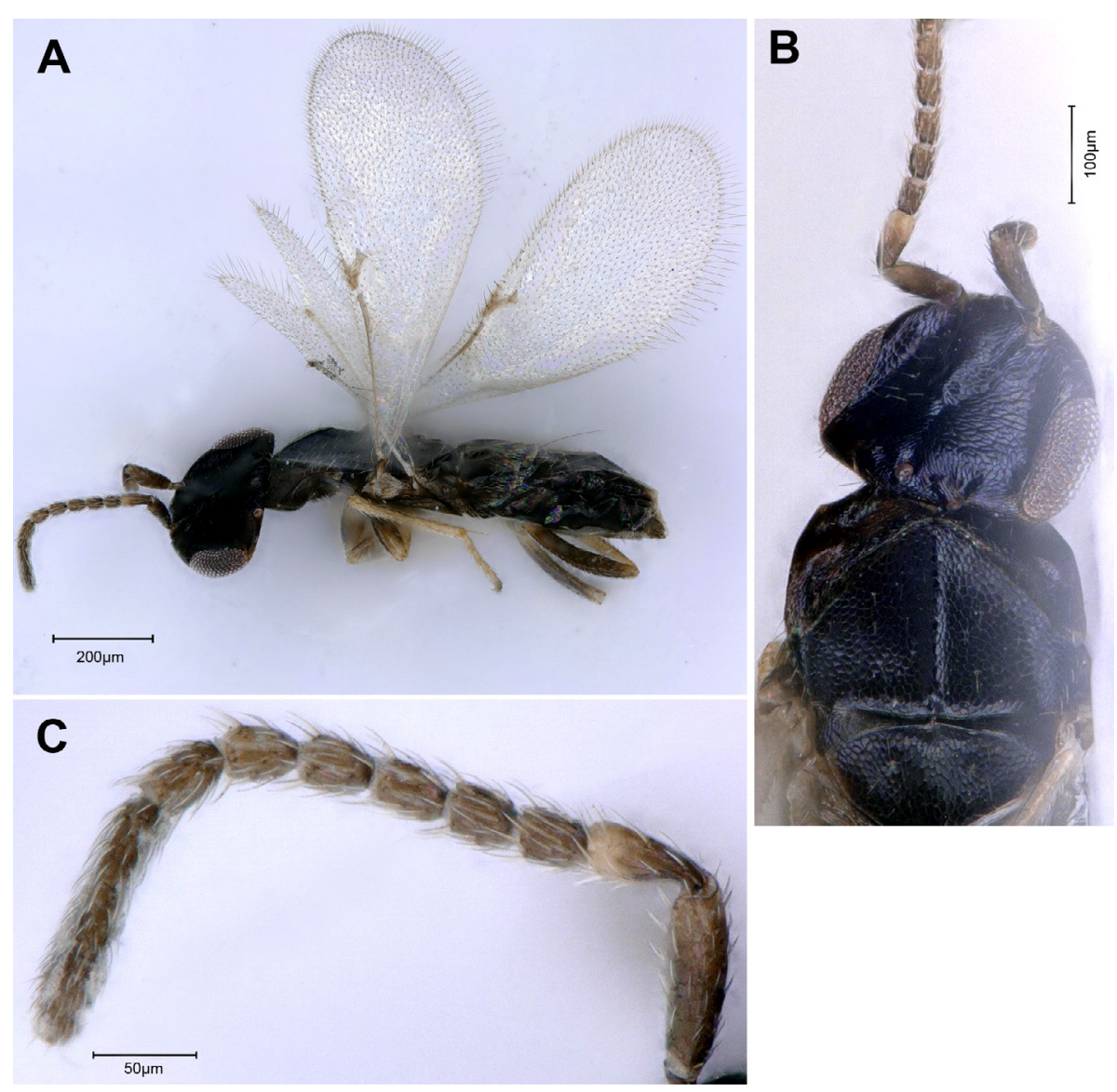

Fig. 2. Asitus sp. A. Male in lateral view. B. Head and mesosoma in dorsal view. C. Antenna of female. 
dorsoventrally flattened; head prognathous, head and mesosoma finely reticulate; antennae inserted just above clypeus and widely separated from each other; pronotum divided into two subtriangular parts; notauli absent; scutellum wider than long, about $1.9 \times$ as wide as long, anteriorly reaching the base of the tegula. However, it differs from A. phragmitis in several characters (Table 2) and in our opinion very probably represents a new species. Because we only sampled a single male, we will not describe this species and await further samples.

Subfamily Encyrtinae Walker, 1837

Tribe Cheiloneurini Hoffer, 1955

Genus Cheiloneurus Westwood 1833

Cheiloneurus paralia (Walker, 1837)

Fig. 3

\section{Material examined}

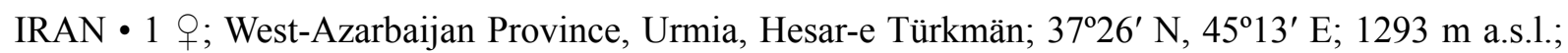
Apr. 2017; Y. Karimpour leg.; ex Phragmites australis; HMIM.

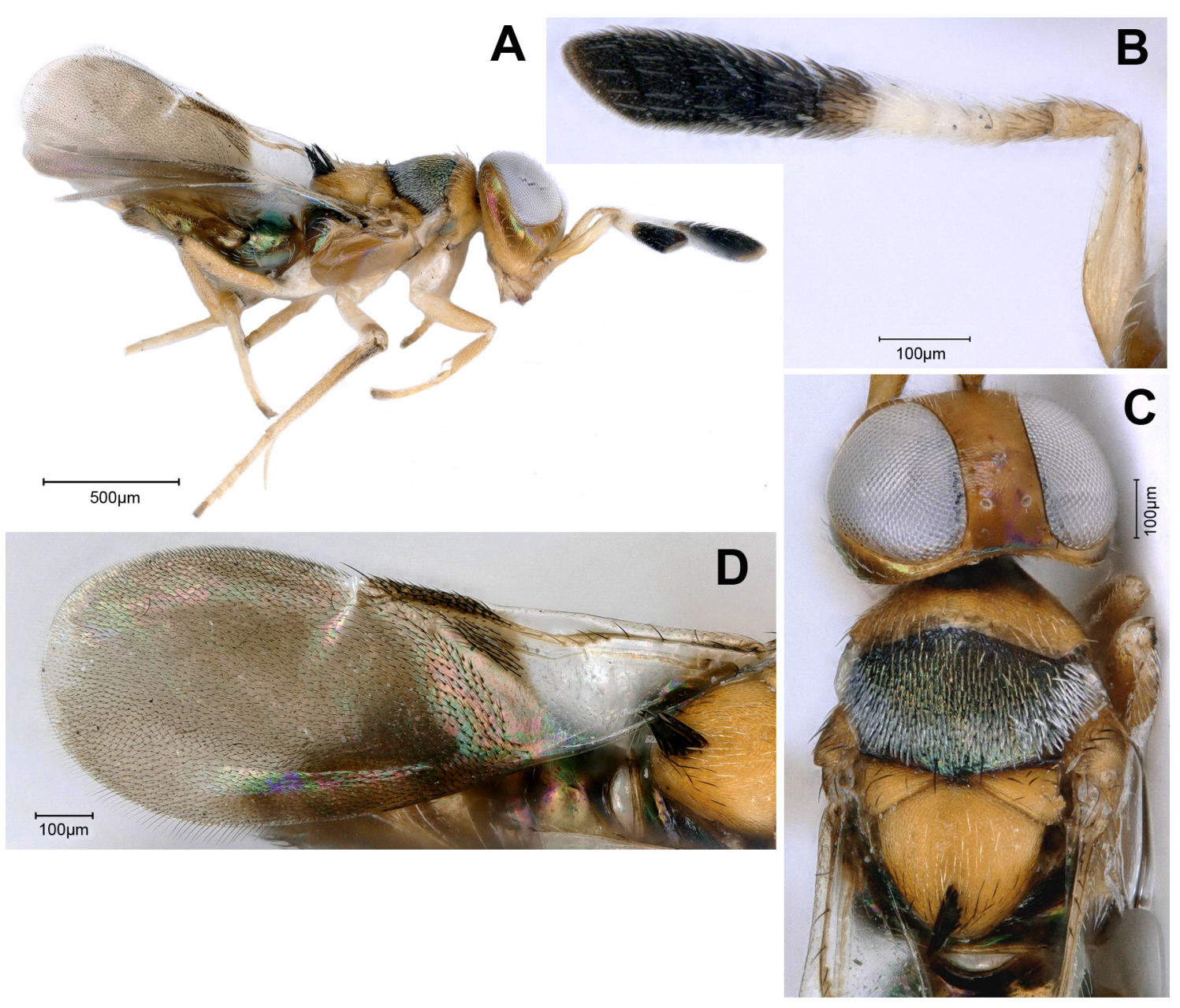

Fig. 3. Cheiloneurus paralia (Walker, 1837). A. Female in lateral view. B.Antenna of female. C. Head, pronotum, mesoscutum and mesoscutellum in dorsal view. D. Fore wing. 


\section{Remarks}

Our specimen fits well the description given by Claridge (1958), but the head exhibits a faint metallicgreen tinge (Fig. 3A, C). Body mainly rufo-fuscous (Fig. 3A), funicle with three white segments, F6 black (Fig. 3B); mesonotum entirely greenish; fore wings mainly fuscous except basally and distally (Fig. 3D); propodeum and abdomen dark with blue-green reflections; scape approximately $5 \times$ as long as wide, funiclar segments almost quadrate, club slightly widened, truncate apically (Fig. 3B); scutellar 'hair-brush' well developed (Fig. 3C); gaster short, as long as thorax.

This species is widely distributed in the Palaearctic region (Noyes 2020) and in Iran (Fallahzadeh \& Japoshvili 2010). Cheiloneurus paralia is a parasitoid of different mealybug families (Asterolecaniidae Cockerell, 1896, Cerococcidae Balachowsky, 1942, Coccidae Stephens, 1829, Eriococcidae Cockerell 1899, Kermesidae Kosztarab, 1996 and Pseudococcidae) on Poaceae such as Festuca rubra L. (Claridge 1958; Noyes 2020). Therefore, it may be associated with a pseudococcid species on P. australis. It has been reported on Peliococcus kimmericus (Kiritshenko, 1940) on Lactuca serriola L. (Asteraceae) in Iran (Fallahzadeh et al. 2006).

Tribe Encyrtini Walker, 1837

Genus Echthroplexiella Mercet, 1921

Echthroplexiella obscura (Hoffer, 1954)

Fig. 4

\section{Material examined}

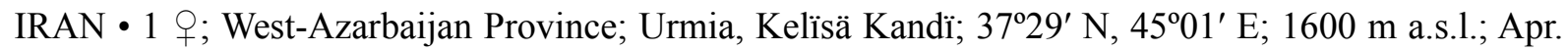
2017; Y. Karimpour leg.; ex Phragmites australis; HMIM.

\section{Remarks}

This species is distributed in the north and east of Europe (Askew 1970; Kalina 1989; Trjapitzin 1989) and represents a new record from Iran. The biology of E. obscura is still unknown, but the species could be associated with a pseudococcid species on P. australis.

Some of the more important diagnostic characters of E. obscura are: body length of female $1.5 \mathrm{~mm}$ (range 1.2-1.6 mm; Trjapitzin 2006); body brownish-yellow to light brown with dark brown metasoma (Fig. 4A); scape much $(4 \times)$ longer than wide, funicular segments wider than long, claval segments fused, obliquely truncate, shorter than the funiculus (Fig. 4C); notauli complete (Fig. 4B); brachypterous, forewing with 2 wide transverse dark bands, middle large band occupying their whole width, distal band broad, faintly fading away to the margin of the wing, hyaline band between the two bands very narrow; marginal vein $2 \times$ as long as broad, postmarginal vein as long as broad, stigma vein a little longer than broad; protruding part of ovipositor sheath longer than $1 / 5$ of the length of metasoma (Fig. 4A).

Genus Neococcidencyrtus Compere, 1928

\section{Type species}

Neococcidencyrtus alula Compere, 1928, by monotypy.

Neococcidencyrtus poutiersi (Mercet, 1922)

Fig. 5

\section{Material examined}

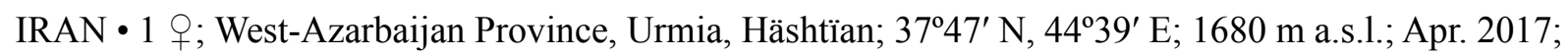
Y. Karimpour leg.; ex Phragmites australis; HMIM. 

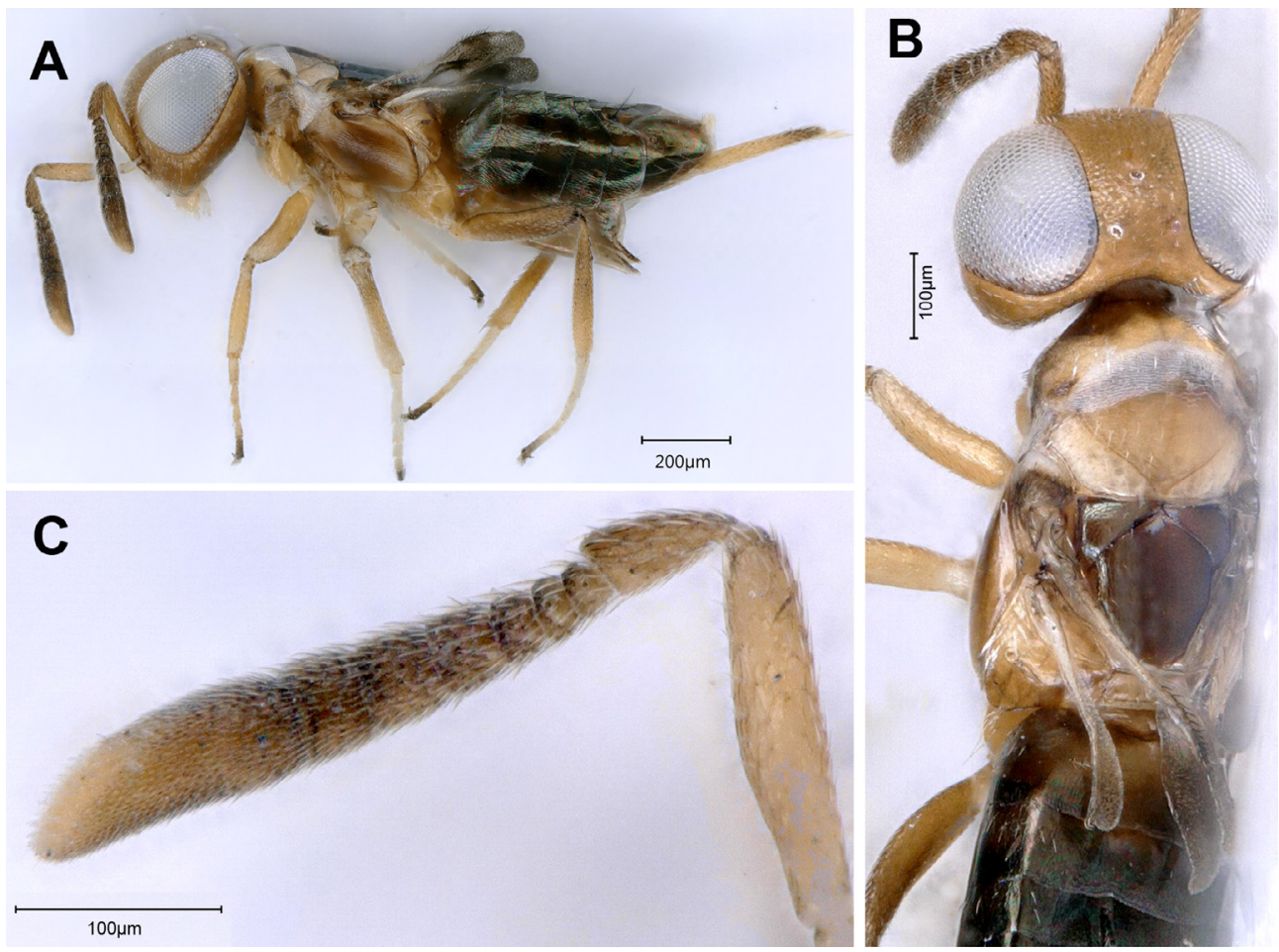

Fig. 4. Echthroplexiella obscura (Hoffer, 1954). A. Female in lateral view. B. Head and mesosoma in dorsal view. C. Antenna of female.

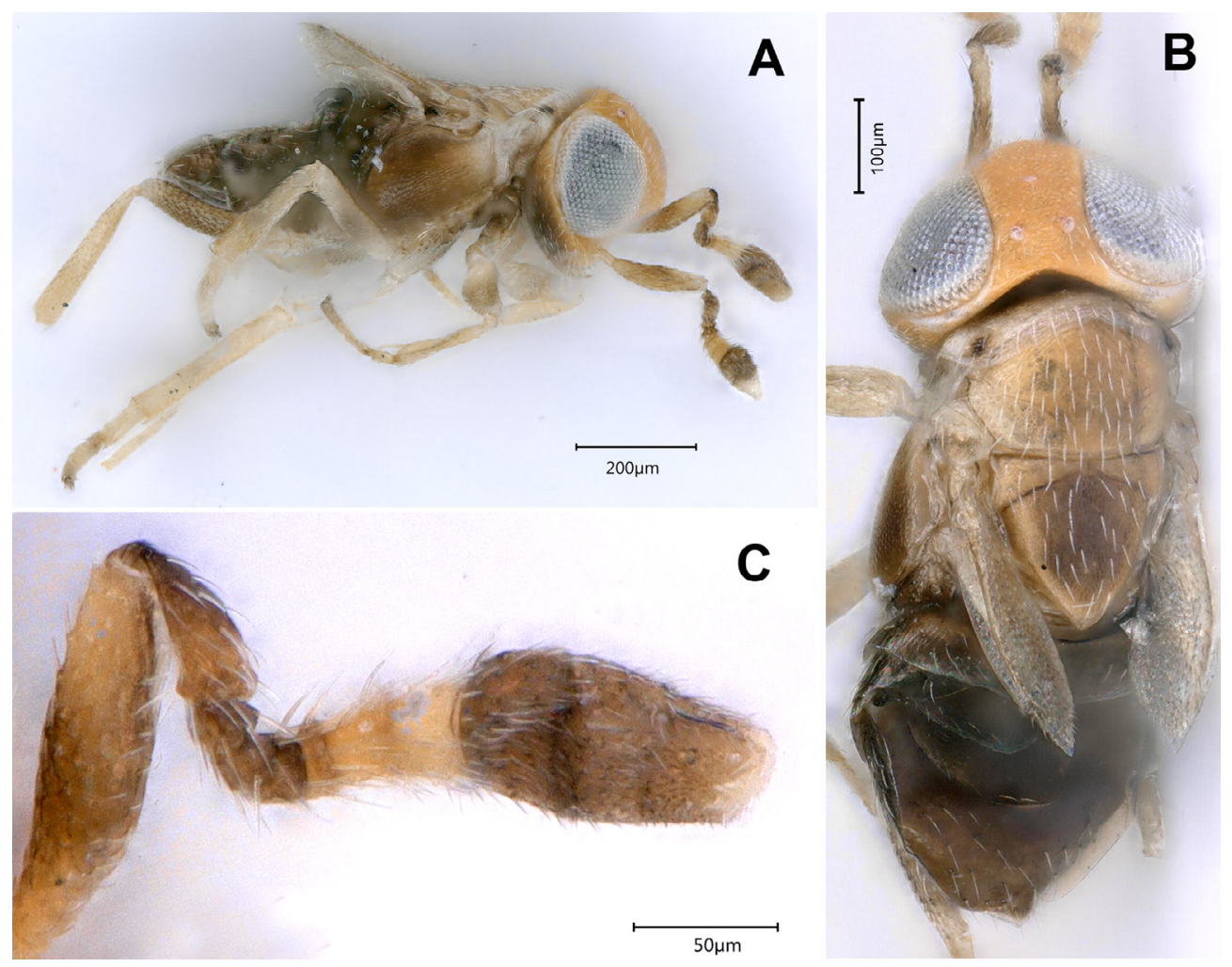

Fig. 5. Neococcidencyrtus poutiersi (Mercet, 1922), ․ A. Lateral view. B. Dorsal view. C. Antenna. 


\section{Remarks}

This species is only known from Turkmenistan and is a parasitoid of Diaspididae Targioni-Tozzetti, 1868 (Hemiptera Linnaeus, 1758) (Noyes 1987, 2020). This is the first record for Iran.

The species is about $2 \mathrm{~mm}$ long; brachypterous (Fig. 5A-B), fore wing mostly infuscate with interrupted hyaline fascia, venation extending over at least two-thirds of wing, linea calva interrupted by $2-3$ setae; fronto-vertex in dorsal view narrower than the eye width (Fig. 5B); funicle in female 6-segmented, F6 about $2 \times$ as broad as the first segment and much broader than the pedicel (Fig. $5 \mathrm{C}$ ).

Family Eulophidae Westwood, 1829

Subfamily Tetrastichinae Graham, 1987

Genus Aprostocetus Westwood, 1833

Aprostocetus orithyia (Walker, 1839)

Fig. 6

\section{Material examined}

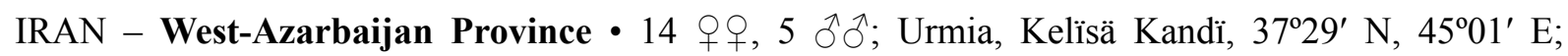

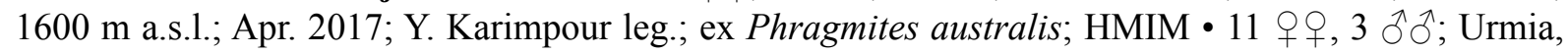

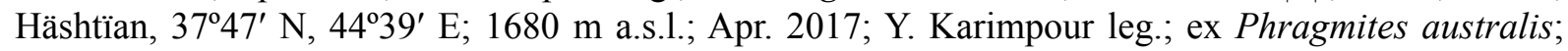

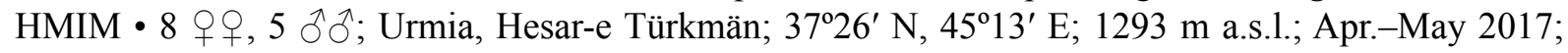
Y. Karimpour leg.; ex Phragmites australis; HMIM.

\section{Remarks}

Aprostocetus orithyia is only known from Europe, develops on fly larvae (Cecidomyiidae and Chloropidae) and this sampling represents a new record for Iran. Aprostocetus orithyia belongs to the lycidas species group (Graham 1987). On P. australis, the species could be a parasitoid of the aforementioned dipterous families.

Main morphological characters: body generally metallic with yellowish tibiae and tarsi (Fig. 6A), antenna with scape as long as the eye, reaching above the level of vertex; funicle very long and slender, 3 -segmented, F1-F2 $3.05 \times$, F3 about $2.6 \times$ as long as broad (Fig. 6B); clava with a relatively shorter and less conspicuous, straight terminal spine. Mid lobe of mesoscutum strongly reticulate (Fig. 6F), areoles

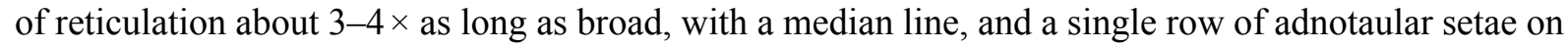
each side. Fore wing apically ciliate, submarginal vein with 2 dorsal setae, speculum absent. Spur of mid tibia longer than half the length of the basitarsus and distinctly longer than the width of the tibia. Metasoma as long as head plus thorax (Fig. 6A).

Family Eupelmidae Walker, 1833

Subfamily Eupelminae Walker, 1833

Genus Eupelmus Dalman, 1820

Eupelmus phragmitis Erdös, 1955

Fig. 7

\section{Material examined}

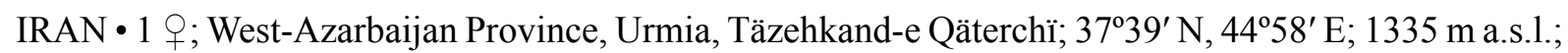
Apr. 2017; Y. Karimpour leg.; ex Phragmites australis; HMIM. 

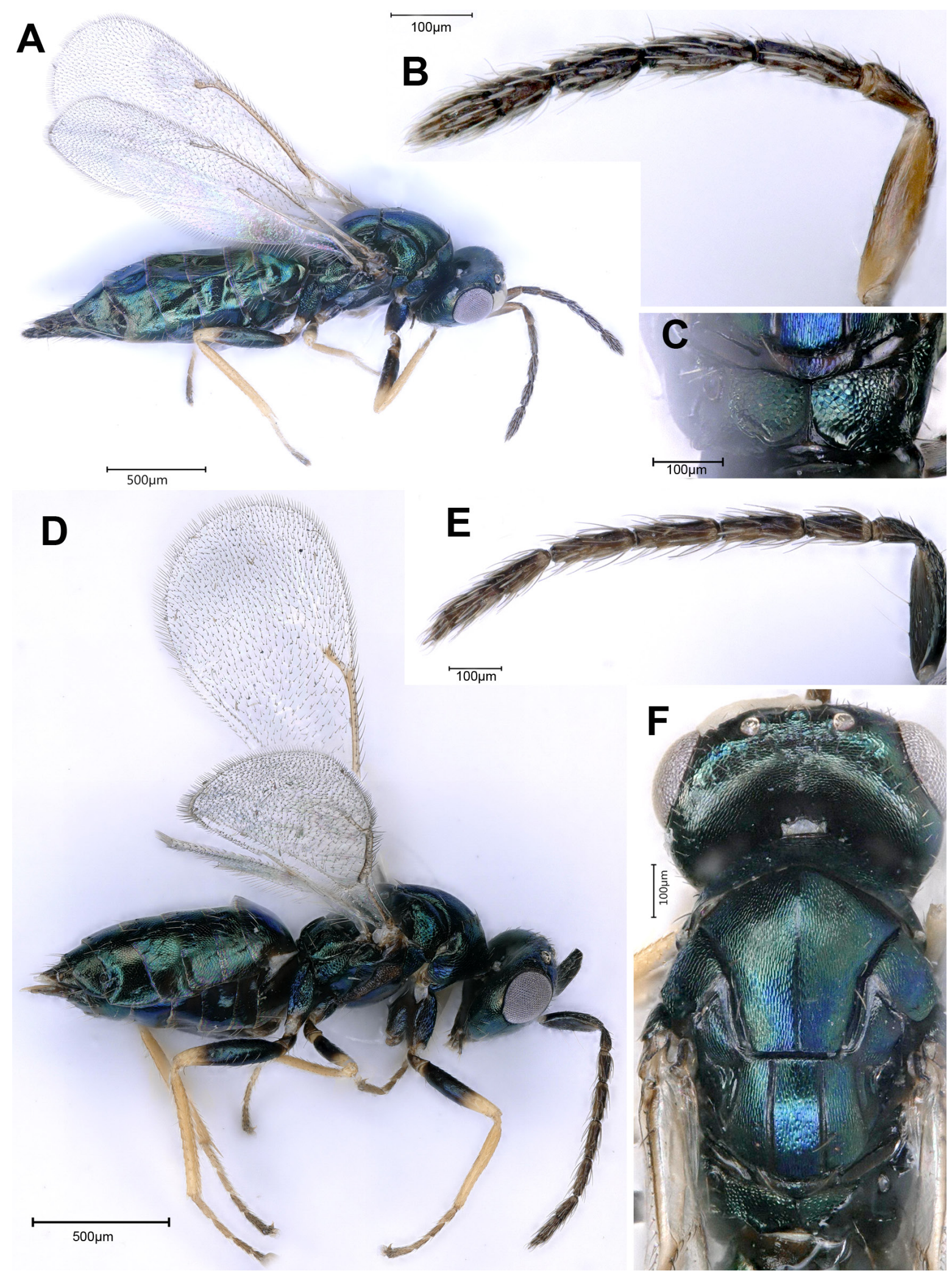

Fig. 6. Aprostocetus orithyia (Walker, 1839). A. Female in lateral view. B. Antenna of female. C. Propodeum in dorsal view. D. Male in lateral view. E. Antenna of male. F. Head and mesosoma of female in dorsal view. 


\section{Remarks}

Eupelmus phragmitis is distributed in the Czech Republic, Greece, Hungary, Israel, Romania, Ukraine and South Korea, and is a parasitoid of Tetramesa phragmitis (Hym.: Eurytomidae) (Gibson \& Fusu 2016). The species may be associated with the same host on P. australis in Iran.

This species belongs to the stramineipes species group (Gibson \& Fusu 2016). All the features of the sampled specimen well match those reported by Gibson \& Fusu (2016), in the couplet 18. It shares the following combination of characters: scrobal depression obviously more deeply reticulate than frontovertex; antennal scape entirely dark, clava lighter than funicle, anellus slightly longer than wide, similarly dark as rest of funicle; fore wing hyaline, infuscate below marginal and stigma veins, dorsally with basal cell and disc uniformly setose except for linea calva, with complete marginal fringe, marginal vein much longer relative to stigma vein; legs sometimes with all femora similarly yellow; ovipositor sheath pale, apparent length of ovipositor sheath distinctly shorter than metatibia. However, it has the following variations: body metallic green (Fig. 7A-B) with obviously golden reflections and reddish-

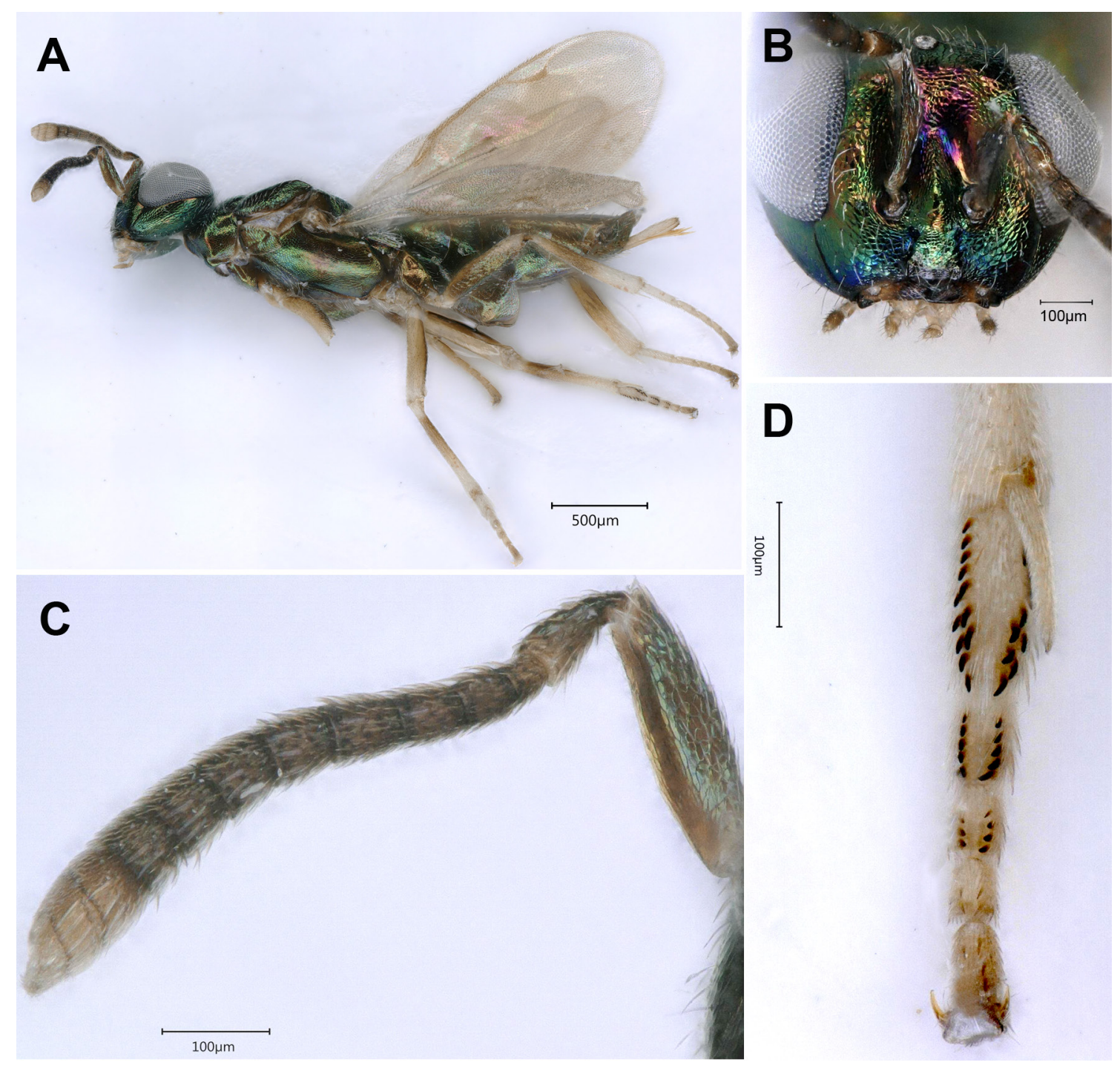

Fig. 7. Eupelmus phragmitis Erdös, 1955. A. Female in lateral view. B. Head in frontal view. C. Antenna of female. D. Mid tarsus in ventral view. 
violet reflections on the scrobal depression, tegula brownish-yellow, legs more extensively pale, slightly darker femur and tibiae medially; F1 less transverse, clava slightly lighter than the rest of antenna (Fig. 7C).

Family Eurytomidae Walker, 1832

Subfamily Eurytominae Walker, 1832

Genus Aximopsis Ashmead, 1904

Aximopsis deserticola (Zerova, 2004) comb. nov.

Fig. 8

\section{Material examined}

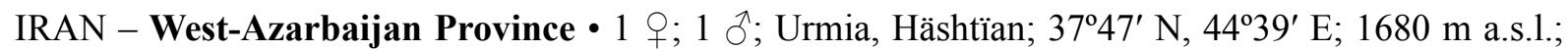
Apr. 2017; Y. Karimpour leg.; ex Phragmites australis; HMIM • 1 q; 1 §ో; Urmia, Hesar-e Türkmän;

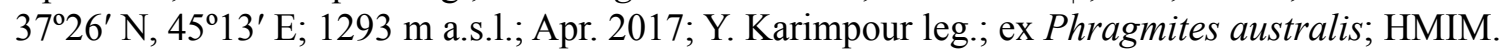

\section{Remarks}

The species has been reported from fruits of Cuscuta approximata Bab. (Cuscutaceae) in Tajikistan and Turkmenistan (Zerova 2010).

This species has characters of the nodularis species group (Lotfalizadeh et al. 2007), and with sharing conspicuous mesopleural shelf, carinate fore coxae and distinctly petiolate gaster, it is consequently transferred from Eurytoma Illiger, 1807 to the genus Aximopsis. Aximopsis deserticola can be separated from closely related species by the following set of characters: head round and slightly wider than long in frontal view (Fig. 8B); inner orbital margin coarsely punctate, and appearing to be slightly carinate; all funicular segments in female distinctly longer than wide (Fig. 8E), F1 about $2.5 \times$ as long as its width; fore coxa distinctly carinate in frontal view; mesopleuron with an obvious ventral shelf, carinate anteriorly and with an oblong comb anteromedially (Fig. 8D); marginal vein as long as postmarginal vein, slightly longer than stigmal vein, postmarginal vein about $1.5 \times$ as long as stigmal vein (Fig. 8C); metasoma of female rounded, as long as mesosoma in lateral view (Fig. 8A), with long petiole, slightly longer than wide.

Genus Tetramesa Walker, 1848

Tetramesa phragmitis (Erdös, 1952)

Fig. 9

\section{Material examined}

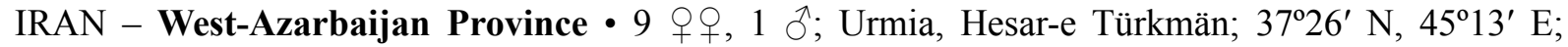

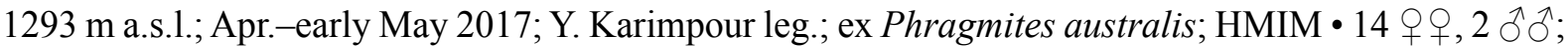
Urmia, Täzehkand-e Qäterchï; 37³9' N, 4458' E; 1335 m a.s.1.; Apr.-early May 2017; Y. Karimpour leg.; ex Phragmites australis; HMIM.

\section{Remarks}

This species is known as a gall-stem wasp of Phragmites australis. Tetramesa phragmitis is widely distributed in the Palaearctic region from Europe to Japan (Bouček 1968; Zerova 1978; Kalina 1989; Zerova \& Fursov 2016).

This species has recently been redescribed (Zerova \& Fursov 2016) and our specimens exhibit the following variations: body larger, $5 \mathrm{~mm}$ (vs 2.7-4.3 $\mathrm{mm}$ in Zerova \& Fursov 2016), mainly dark, 

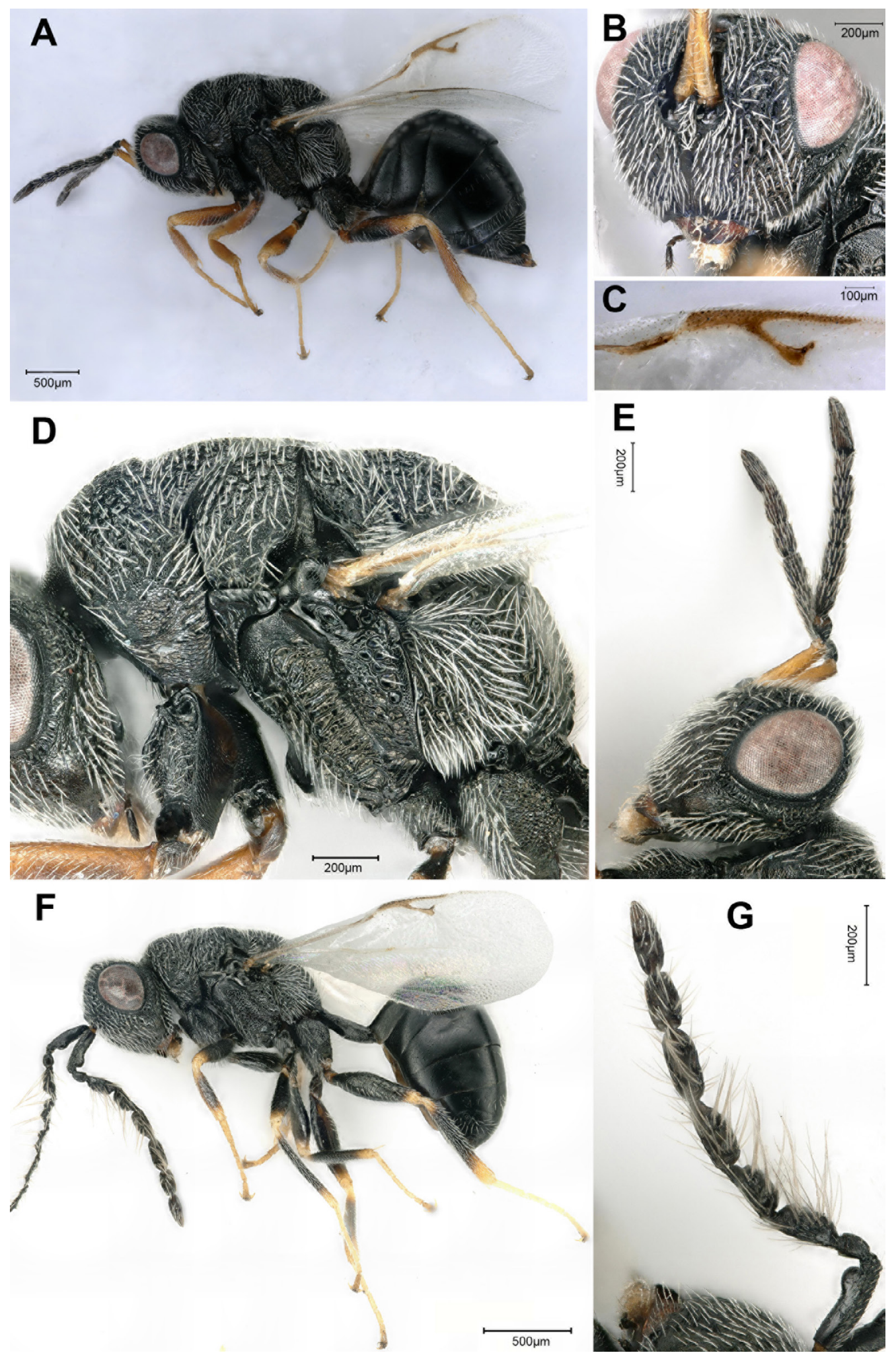

Fig. 8. Aximopsis deserticola (Zerova, 2004) comb. nov. A. Female in lateral view. B. Head of female in frontal view. C. Fore wing venation. D. Mesosoma in lateral view. E. Head and antennae in lateral view. F. Male in lateral view. G. Male antenna. 
with yellow spots reduced to head, below eyes and lower face (Fig. 9A, E) vs yellow spots on head and thorax, also much lighter specimens occur in Israel and Tajikistan (Zerova \& Fursov 2016). Fore wing (Fig. 9C) mainly infuscate with two distinct dark spots, the first one under marginal and stigmal veins and the second as a V-shaped dark spot below submarginal vein vs unclear yellow spot under marginal vein (Zerova \& Fursov 2016); and distinctly dark-brown veins vs yellowish veins (Zerova \& Fursov 2016).
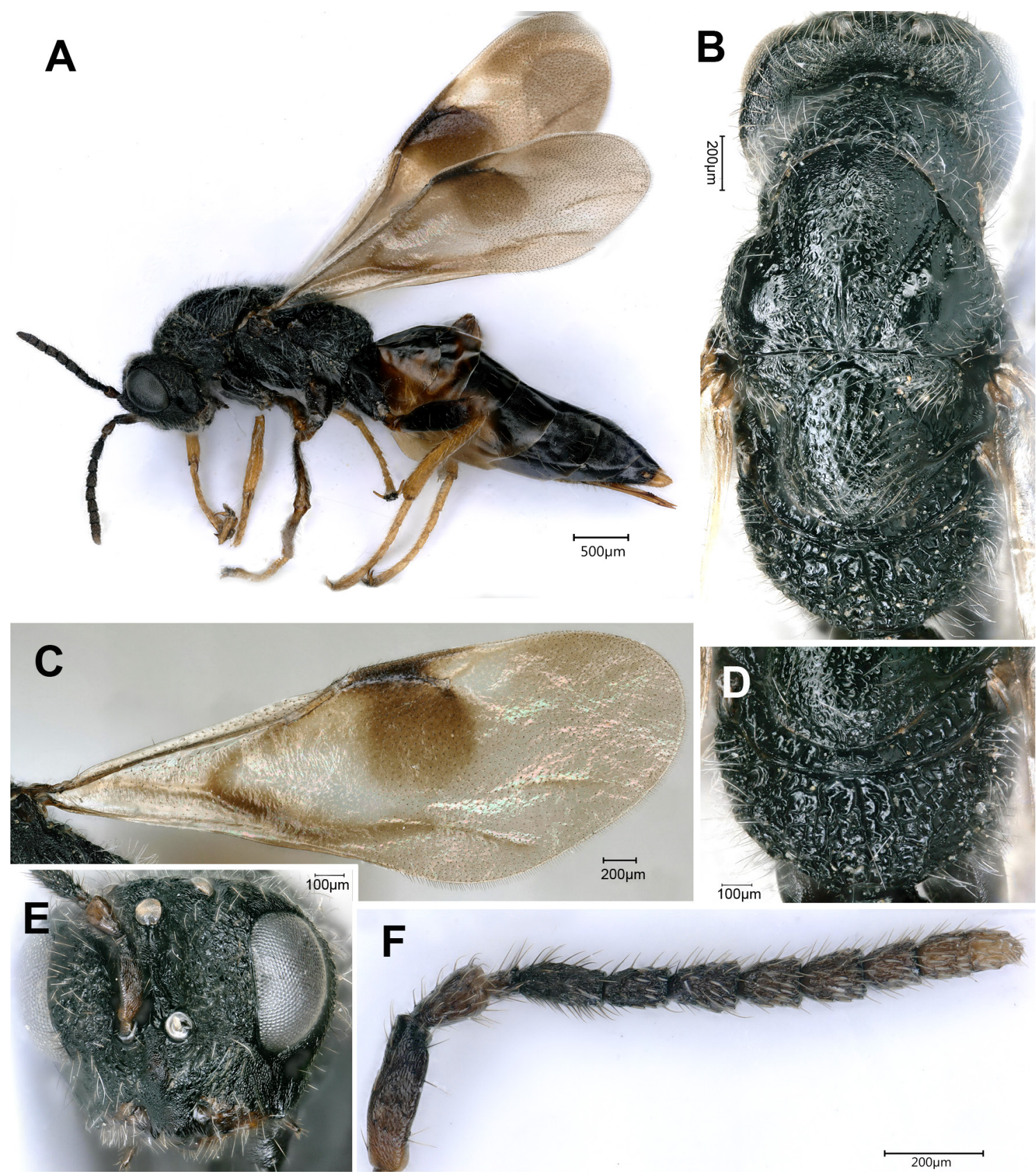

Fig. 9. Tetramesa phragmitis (Erdös, 1952). A. Female in lateral view. B. Head and mesosoma in dorsal view. C. Fore wing. D. Propodeum in dorsal view. E. Head in frontal view. F. Antenna of female. 
Genus Tetramesa Walker, 1848

Tetramesa sp.

Fig. 10

\section{Material examined}

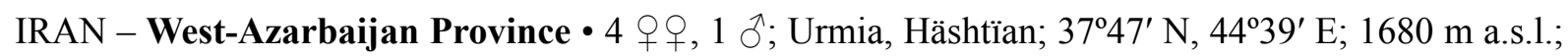
Apr. 2017; Y. Karimpour leg.; ex Phragmites australis; HMIM • 3 우; Urmia, Hesar-e Türkmän; $37^{\circ} 26^{\prime}$ N, 4513' E; 1293 m a.s.l.; Apr. 2017; Y. Karimpour leg.; ex Phragmites australis; HMIM.

\section{Remarks}

Only T. phragmitis has previously been reported from Phragmites spp. (Noyes 2020). Based on the key of Claridge (1961), our specimens are closely related to Tetramesa cornuta (Walker, 1832) in the couplet 17, sharing with this species the following characters: funicular segments short with F5 quadrate;

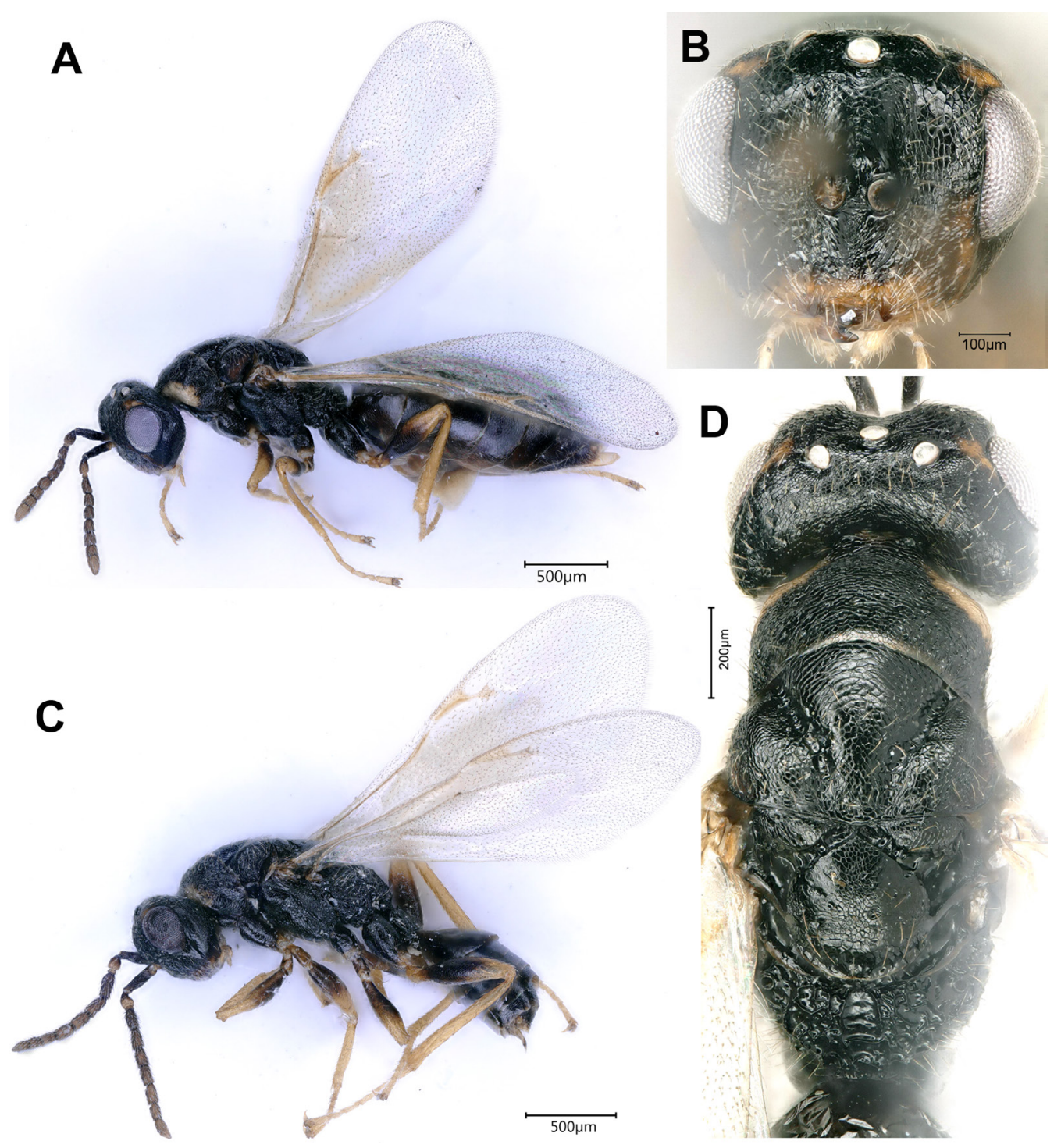

Fig. 10. Tetramesa sp. A. Female in lateral view. B. Head of female in frontal view. C. Male in lateral view. D. Head and mesosoma in dorsal view. 
pronotum transverse (Fig. 10D), about $2 \times$ as wide as long; mid tibial spur relatively long, longer than half length of basitarsus; longer GT3 non-emarginate posteriorly. However, the female appears to be larger than is reported for T. cornuta; marginal vein at most as long as stigmal vein (vs marginal vein twice as long as stigmal vein in $T$. cornuta); metasoma longer than the combined length of head plus mesosoma (75:65) (vs metasoma shorter than combined length of head and mesosoma in T. cornuta). In the male, the funicular segments are slightly longer than in the female (Fig. 10C) but a more distinct sexual dimorphism was observed in T. cornuta (Claridge 1961: figs 97-98). This species clearly is different from T. cornuta and may be new. However, further specimens are required and we also need to examine several type specimens belonging to the genus Tetramesa to ascertain its novelty.

Family Pteromalidae Dalman, 1820

Subfamily Pteromalinae Dalman, 1820

Genus Homoporus Thamson, 1878

Homoporus febriculosus (Girault, 1917)

Figs $11-12$

\section{Material examined}

IRAN - West-Azarbaijan Province • 4 우, 1 ð̊; Urmia, Kelïsä Kandï; $37^{\circ} 29^{\prime}$ N, $45^{\circ} 01^{\prime}$ E; 1600 m a.s.l.; Apr.-early May 2017; Y. Karimpour leg.; M.-D. Mitroiu det.; ex Phragmites australis; HMIM • 8 우,

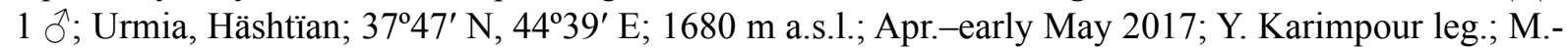

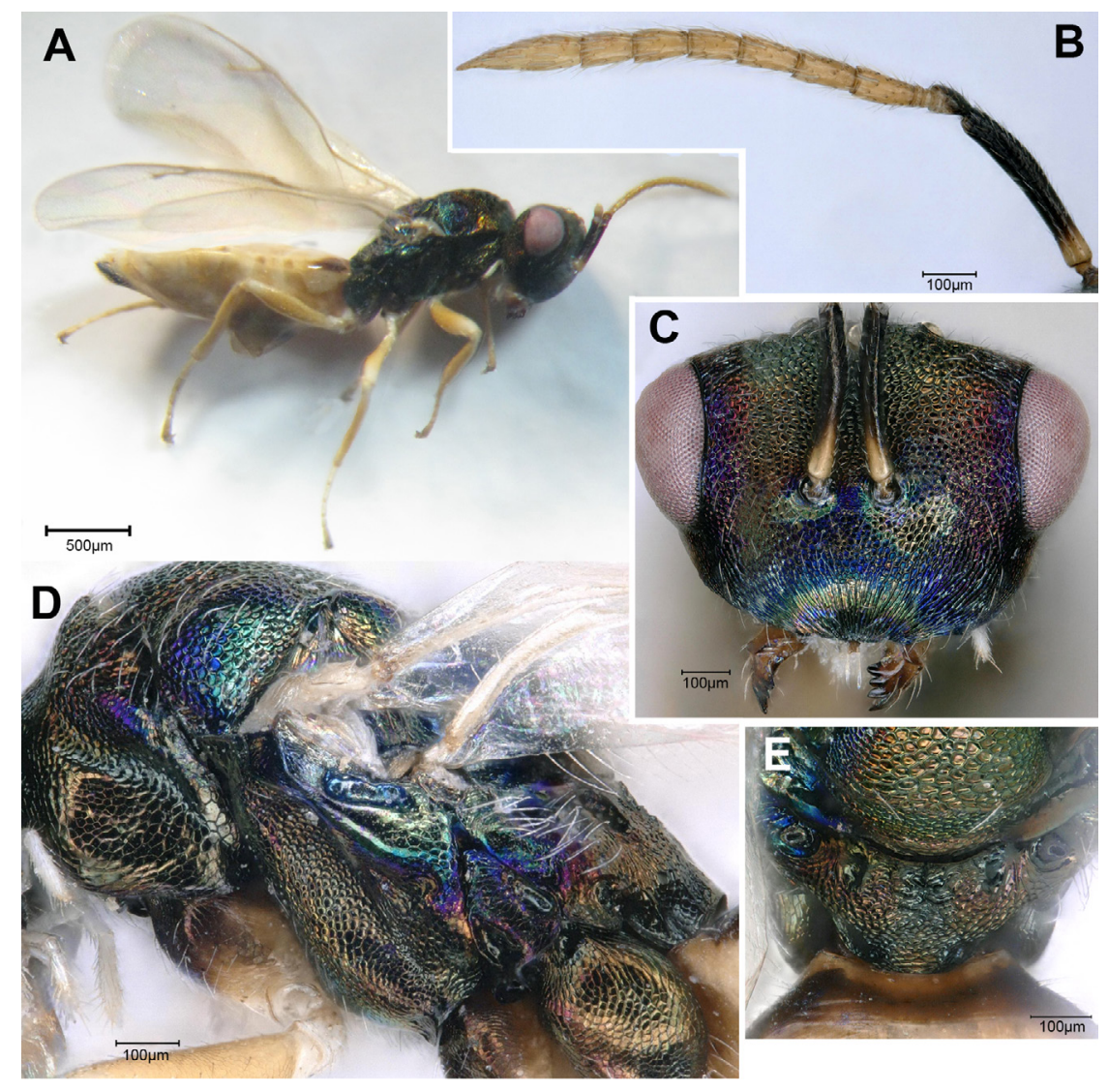

Fig. 11. Homoporus febriculosus (Girault, 1917), female. A. Lateral view. B. Antenna. C. Head in frontal view. D. Metasoma in lateral view. E. Head in dorsal view. 
D. Mitroiu det.; ex Phragmites australis; HMIM • 2 + $\odot$; Urmia, Hesar-e Türkmän; $37^{\circ} 26^{\prime}$ N, $45^{\circ} 13^{\prime}$ E; 1293 m a.s.1.; Apr.-early May 2017; Y. Karimpour leg.; M.-D. Mitroiu det.; ex Phragmites australis; $\mathrm{CBGP} \bullet 1$, same collection data as for preceding; HMIM

\section{Remarks}

Homoporus febriculosus is a Palaearctic species that is distributed from UK to Turkey and also reported from Canada (Noyes 2020). It is known as a parasitoid of some Diptera (Agromyzidae, Cecidomyiidae, Chloropidae) and Hymenoptera (Braconidae Latreille, 1829, Cephidae Newman, 1834 and Eurytomidae) and in our rearing, it seems to be parasitoid of Tetramesa spp. (Eurytomidae) and Lipara spp. (Chloropidae) associated with P. australis.

All the characters of the sampled specimens well match those reported by Gahan (1933) with the following variations: much larger, body length of females vary from 3.3 to $3.8 \mathrm{~mm}$ and males from 2.5

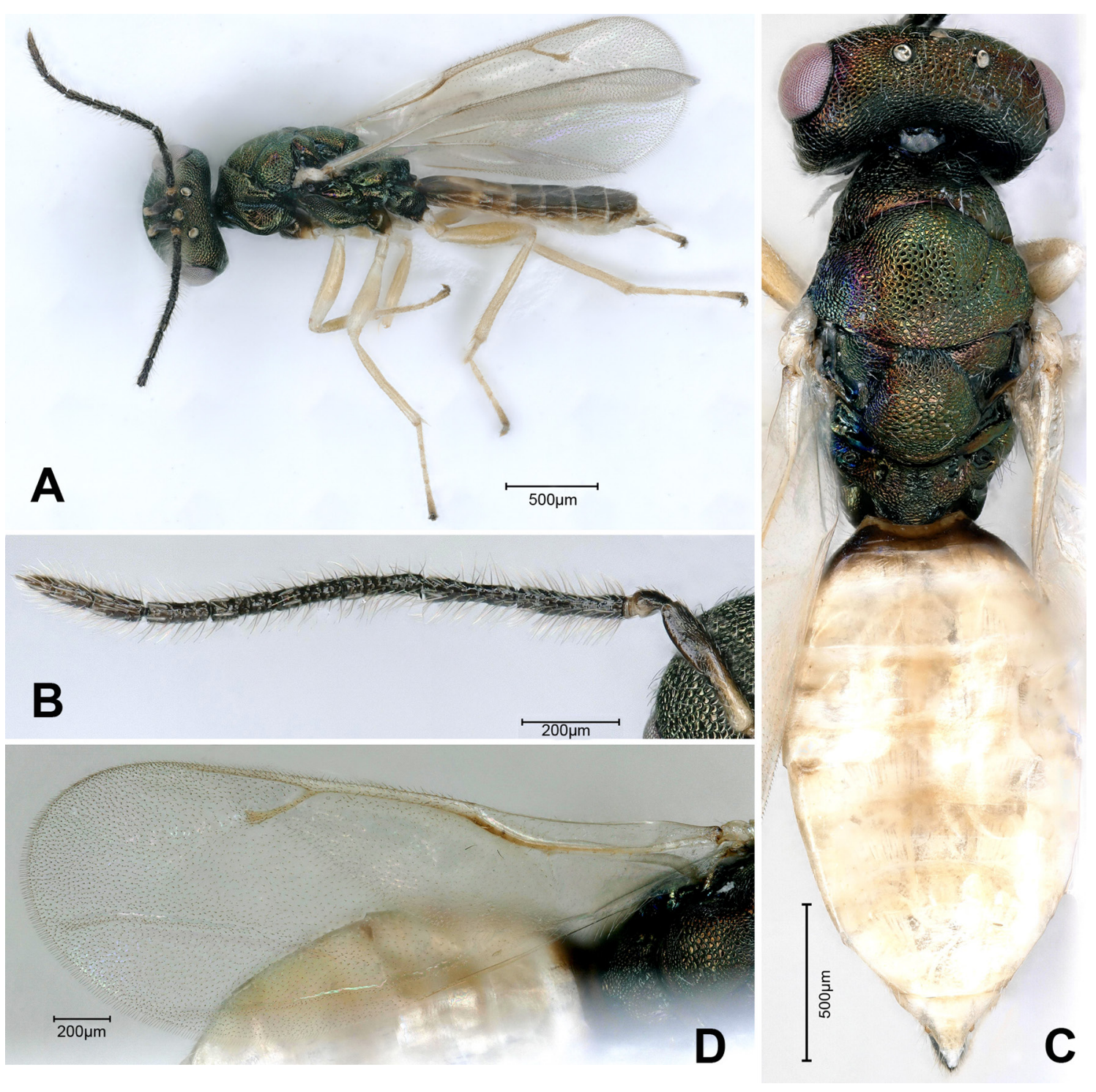

Fig. 12. Homoporus febriculosus (Girault, 1917). A. Male in lateral view. B. Male antenna. C. Female in dorsal view. D. Fore wing of female. 
to $3.17 \mathrm{~mm}$ vs female $2-2.8 \mathrm{~mm}$ and males $1.2-2.3 \mathrm{~mm}$ (Gahan 1933); head and mesosoma dark, with slight metallic greenish-blue to violet tinge versus dark metallic green (Gahan 1933).

Genus Norbanus Walker, 1843

Norbanus Walker, 1843: 159.

Type species

Norbanus dysaules Walker, 1843, designated by Ashmead (1904).

Norbanus persicus Lotfalizadeh \& Rasplus sp. nov. urn:1sid:zoobank.org:act:285A4E43-0EF3-452C-9757-A51ACABE9DAA

Figs 13-14

\section{Diagnosis}

Relatively large species (3.45-4.17 mm); metallic green mesosoma and brown metasoma; in female all funicular segments long longer than broad, F1 about $3.7 \times$ as long as broad; in male funicular segments filiform, long and not pedicellate; clypeus dorsally strigose; hind margin of first tergite straight or slightly convex in posterior part; fore wing of male and female with basal cell and basal vein entirely bare especially in basal half, postmarginal vein shorter than marginal vein.

\section{Etymology}

This species is named after the ancient name of Iran (Persia).

\section{Material examined}

\section{Holotype}

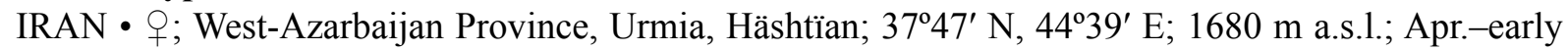
May 2017; Y. Karimpour leg.; ex Phragmites australis; HMIM.

\section{Paratypes}

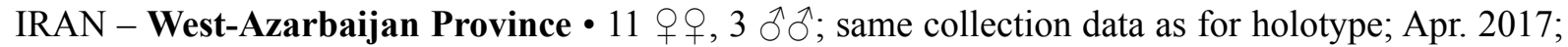

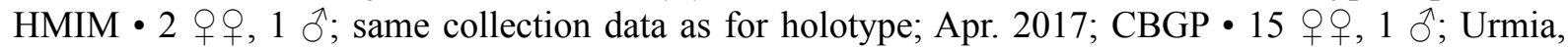

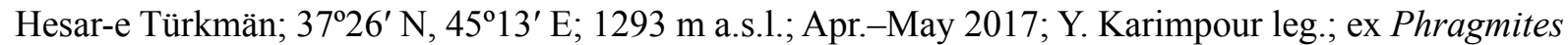
australis; HMIM • 6 q 9 ; Urmia, Täzehkand-e Qäterchï; $37^{\circ} 39^{\prime}$ N, $44^{\circ} 58^{\prime}$ E; 1335 m a.s.1.; Apr.-early May 2017; Y. Karimpour leg.; ex Phragmites australis; HMIM.

\section{Description}

Female holotype (Fig. 13A)

BODY LENGTH. $3.85 \mathrm{~mm}$.

CoLor. Head and mesosoma black, with slight metallic greenish reflections, metasoma brown without metallic reflections. Eyes brownish. Ocelli honey-yellow. Pilosity on the body long and whitish. Mandibles brown, teeth dark brown. Antenna (Fig. 13C) brown with scape, light brown to yellow distally, clava yellow. Coxae brown, femora brown medially and yellow apically and basally, all tibiae and tarsi pale yellow, claws and arolia darker. Wings hyaline, tegula and wing venation yellowish-brown (Fig. 14D), wing setae dark. 
HEAD. Reticulate, lower face finely striated, striation not reaching halfway to level of toruli; head in dorsal view slightly wider than mesosoma (18:15) (Fig. 13B), $2 \times$ as broad as long (18:9). Scrobes shallow, almost invisible in dorsal view. Temple short, in dorsal view a little less than half length of eye (Fig. 13B). POL slightly longer than OOL (35:33) and $2.3 \times$ distance between anterior and posterior ocelli. Head in frontal view $1.23 \times$ as broad as high (Fig. 13E); malar space $0.64 \times$ eye height (35:55). Eyes separated by $1.7 \times$ their height; eye height about $1.48 \times$ length; anterior margin of clypeus emarginate (Fig. $11 \mathrm{E})$; lower margins of toruli distinctly above level of lower margins of eyes (Fig. 13E). Antennal formula: 11263; antennal scape $5.7 \times$ longer than wide (80:14), longer than eye height (33:25), reaching to beyond

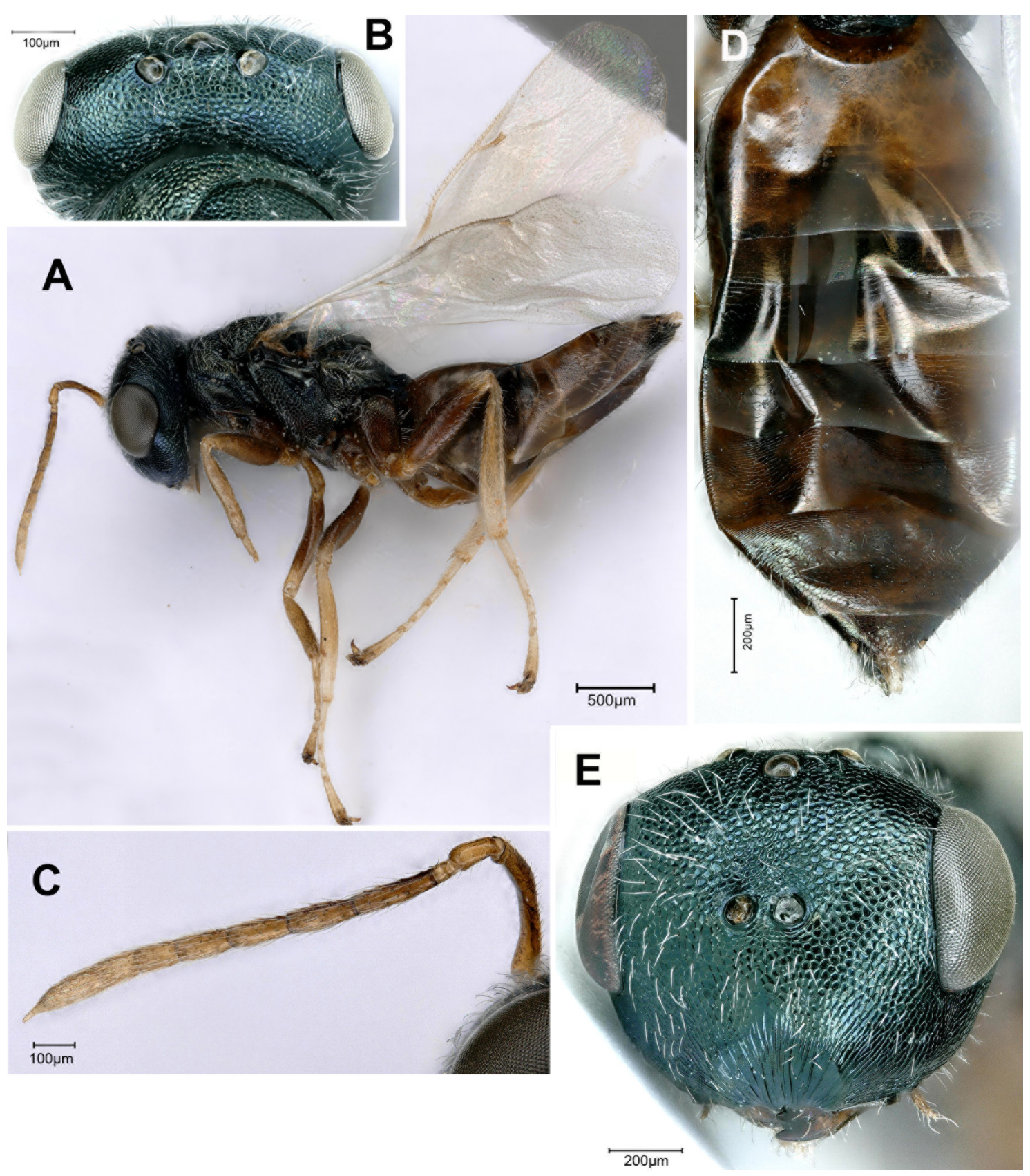

Fig. 13. Norbanus persicus Lotfalizadeh \& Rasplus sp. nov., paratype, $q$ (HMIM). A. Lateral view. B. Head in dorsal view. C. Antenna. D. Metasoma in dorsal view. E. Head in frontal view. 
median ocellus; pedicel plus funicle $1.16 \times$ as long as head width (70:60); pedicel in dorsal view $2 \times$ as long as broad and $1.8 \times$ as long as anelli; all funicular segments longer than broad (Fig. 13C), flagellum slightly clavate, $1^{\text {st }}$ anellus transverse, the second quadrate, about $1.8 \times$ as long as the first (9:5), F1 1.8 $\times$ longer than pedicel and longer than each of F2-F6, relative measurements: F1 (54:13), F2 (45:15), F3 (40:15), F4 (35:15), F5 (29:16), F6 (25:17); clava $3.05 \times$ as long as broad and slightly longer than combined length of F5 and F6 (55:54), with conspicuous spicula at apex; each funicular segment and 2 basal claval segments at least with 2 sparse rows of placoid sensilla.

Mesosoma. In dorsal view $1.47 \times$ as long as broad, mesosomal length: 120 , width: 75 , height: 65 . Pronotum $3.2 \times$ as broad as long (62:19); mesoscutum $1.1 \times$ as broad as long (85:75), dull, finely reticulate, with long white setae. Notauli incomplete, reaching to about half length of mesoscutum, with reticulations on lateral lobes of mesoscutum finer medially. Scutellum slightly shorter than mesoscutum (84:98) and about as wide as long, moderately convex, frenal line absent, but frenal area with finer reticulation than rest of scutellum, with normal pilosity. Upper mesepimeron smooth. Metapleuron and dorsellum uniformly reticulate. Propodeum $0.57 \times$ as long as scutellum (48:84), uniformly reticulate except two small depressions near its anterior margin submedially, spiracle oval and separated from metanotum by its lesser diameter.

ForE WING (Fig. 13A, D). Length $2.40 \times$ width (220:92); with basal cell and basal fold glabrous; costal cell with one row of setae on ventral surface and a few additional setae distally; basal cell open below; speculum large, extending to stigmal vein; wing pilosity including marginal fringe short; stigma hardly capitate. Relative measurements, costal cell: 85; M: 37; S: 17; PM: 28.

Metasoma (Fig. 13D). Ovate acuminate, dorsally slightly reticulate-imbricate, except for T1 which is mainly smooth, $2 \times$ as long as broad (136:68), slightly shorter than head plus mesosoma (136:145), and $1.24 \times$ as long as mesosoma (136:110); hind margin of T1 straight, T1 about $1 / 3$ of metasoma length (45:136); hind margins of T2 and T3 straight. Ovipositor sheaths short, not visible in dorsal view (Fig. 13A).

\section{Male (Fig. 14B)}

Smaller than female. Scape and pedicel usually yellowish-brown, exceeding level of vertex by slightly less than one quarter scape length (Fig. 14B); funicular segments long and thin, with uniform width, covered with whorls of long and dense setae; pedicel plus flagellum $0.74 \times$ head plus mesosoma; proximal funicular segments usually not widened distally, F1-7 gradually decreasing in length, each segment with more than one row of placoid sensilla.

\section{Variation}

Body length of females varies from $2.67-5.40 \mathrm{~mm}$ and males from $3.45-4.17 \mathrm{~mm}$. Antennae of female in smaller specimens entirely yellow. Metasoma and femura of female dark-brown to dark in some specimens. Metasoma of males darker than females. Wings slightly fuscate, especially in larger specimens but entirely hyaline in smaller specimens.

\section{Biological association}

Host unknown. This species was reared from Phragmites australis in northwest Iran. Within the reared phytophagous insects, Chilo phragmitella (Hübner, 1810) (Lepidoptera: Crambidae) is its most likely host.

\section{Distribution}

Only known from Iran. 


\section{Remarks}

The species closely resembles $N$. tenuicornis Bouček, 1970 known from Europe, Africa and China. It mainly differs in body size and coloration, and some antennal characters. Detailed diagnostic features of both species are provided in Table 3 .

The male of this species is similar to that of the genus Gugolzia Delucchi \& Steffan, 1956 in having the antennae inserted far above the center of the face, but the distinct antennal spicula of $N$. persicus Lotfalizadeh \& Rasplus sp. nov. (less visible in Fig. 14C, due to whorls of long and dense setae) runs it to the group of pteromalids with spiculated antennae that males in the genus Gugolzia miss. In addition, the

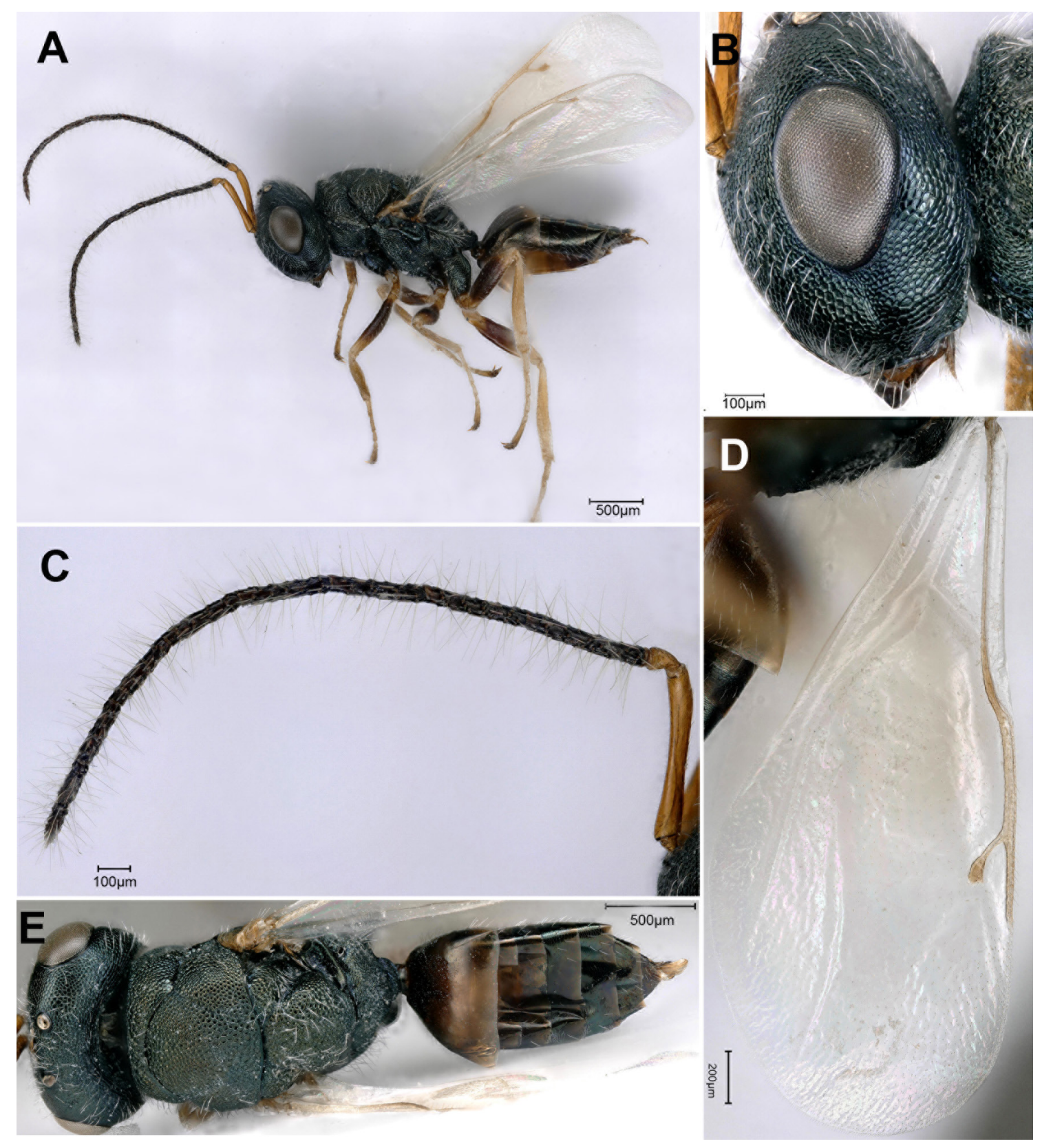

Fig. 14. Norbanus persicus Lotfalizadeh \& Rasplus sp. nov., paratype, $ぇ$ (HMIM). A. Lateral view. B. Head in lateral view. C. Antenna. D. Fore wing. E. Dorsal view. 
Table 3. Features distinguishing both sexes of Norbanus persicus Lotfalizadeh \& Rasplus sp. nov. from N. tenuicornis Bouček, 1970.

\begin{tabular}{|c|c|c|}
\hline Morphological features & $\begin{array}{c}\text { N. persicus Lotfalizadeh \& } \\
\text { Rasplus sp. nov. } \\
\text { Figs 13-14 }\end{array}$ & $\begin{array}{l}\text { N. tenuicornis Bouček, } 1970 \\
\text { (Mitriou 2015: figs 195-200) }\end{array}$ \\
\hline Body length $(+)$ & Large species (about $3.8 \mathrm{~mm}$ ) & Small species (less than $2 \mathrm{~mm}$ ) \\
\hline Coloration, body $(\widehat{\partial} \&$ +$)$ & Metallic green & Metallic blue \\
\hline Coloration, gaster $(+)$ & $\begin{array}{l}\text { Brown, without metallic } \\
\text { reflections }\end{array}$ & Blue metallic \\
\hline Coloration, funicular segments $\left({ }^{\lambda}\right)$ & Dark & Pale brown \\
\hline Antennal funicular segments $(+)$ & $\begin{array}{l}\text { Longer }(\mathrm{F} 1 \text { about } 3.7 \times \text { as } \\
\text { long as broad })\end{array}$ & $\begin{array}{l}\text { Shorter (F1 about } 2 \times \text { as long } \\
\text { as broad) }\end{array}$ \\
\hline Position of toruli on face $(\stackrel{P}{+})$ & Closer to median ocellus & $\begin{array}{l}\text { Equidistant from median } \\
\text { ocellus and ventral margin of } \\
\text { clypeus }\end{array}$ \\
\hline Sculpture of clypeus dorsally $(+)$ & Strigose & Mostly reticulate \\
\hline Shape of funicular segments $(\circlearrowleft)$ & Filiform & Pedicellate \\
\hline
\end{tabular}

female shares 2-segmented annelli (vs 3-segmented annelli in Gugolzia), distinctly spiculated antennae and distinctly small prepectus runs to the genus Norbanus.

The key to the species of Norbanus in the Palaearctic (Rizzo \& Mitroiu 2010) was updated (see Appendix), including the female and male of the new species of Norbanus described above, N. rasplusi Lotfalizadeh, 2015 (Lotfalizadeh 2015) as well as the male of $N$. tenuicornis.

Genus Stenomalina Ghesquière, 1946

Stenomalina delvarei Lotfalizadeh \& Rasplus sp. nov. urn:lsid:zoobank.org:act:6155E1F4-0120-4217-ACAD-F08E1EDC2729

Figs $15-16$

\section{Diagnosis}

Clypeus medially pointed and with lateral teeth, dorsally finely strigose; malar space slightly more than half the length of an eye; pedicel + flagellum $0.9 \times$ as long as head width, elongate funicular segments (distinctly longer than wide); temple converging slightly behind the eye dorsally, slightly more than $1 / 3$ as long as eyes; propodeum, with an inverted Y-shaped median carina; costal cell ventrally with three rows of short setae near dorsal margin; basal third of wing bare, postmarginal vein longer than marginal and stigma veins; metasoma lanceolate, short, $1.7 \times$ as long as broad, relatively shorter metasoma (shorter than head + mesosoma).

\section{Etymology}

We dedicate this species to our friend Gérard Delvare for his overall contribution to the taxonomy of Chalcidoidea. 


\section{Material examined}

Holotype

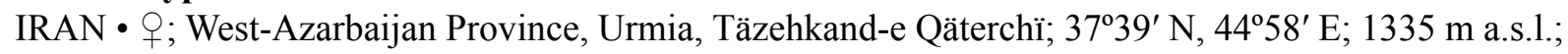
Apr. 2017; Y. Karimpour leg.; ex Phragmites australis; HMIM.

\section{Paratypes}

IRAN - West-Azerbaijan Province 1 1 , 1 §; same collection data as for holotype; HMIM • 1 ;

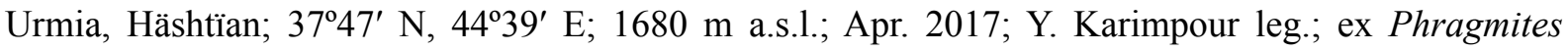
australis; CBGP $\bullet 1$ ${ }^{\lambda}$; same collection data as for preceding; HMIM.

\section{Description}

Female (holotype)

BODY LENGTH. $3.85 \mathrm{~mm}$.

CoLor. Head and mesosoma dark with metallic green reflection (Fig. 15D); metasoma dark dorsally, T1 with green, golden and violet reflections(Fig. 15D); antennal scape, pedicel and anelli yellowishbrown, flagellum black (Fig. 15B); coxae concolorous with mesosoma, distally brown, trochanters yellow, femora brown, distally and basally yellow; tibiae and tarsi whitish-yellow, last tarsal segments brownish, pretarsi fuscous. Tegula brownish. Forewing slightly infuscate below marginal vein; rest of wing, and the hindwing hyaline; venation brown. Wing setae dark (Fig. 15E).

HeAD. Reticulate, with finer reticulation in scrobes and on lower face, clypeus dorsally finely striated, clypeal margin pointed medially with lateral teeth (Fig. 16B), striation reaching half way to level of toruli; head in dorsal view as wide as mesosoma (Fig. 15D), 2.2 $\times$ as broad as long (112:50). Scrobes shallow, almost invisible in dorsal view. Temple relatively long, in dorsal view a little less than length of eye (23:28) (Fig. 15D). POL shorter than OOL (23:28) and $1.5 \times$ distance between anterior and posterior ocelli (23:15). Head in frontal view $1.32 \times$ as broad as high (150:114) (Fig. 16B); malar space $0.63 \times$ eye height (40:64). Eyes separated by $1.7 \times$ their height (102:58); eye height about $1.33 \times$ length $(64: 48)$; anterior margin of clypeus slightly toothed medially (Fig. 16B); lower margins of toruli distinctly above level of lower margins of eyes (Fig. 16B). Antennal (Fig. 15B) formula: 11253; antennal scape $6.8 \times$ longer than wide (115:18), shorter than eye height (115:139), reaching to median ocellus, inserted approximately mid-way between the anterior margin of the clypeus and the median ocellus; pedicel plus flagellum $0.9 \times$ as long as head width (112:104); pedicel in dorsal view $1.75 \times$ as long as broad (35:20) and $2.3 \times$ as long as anelli (35:15); funicular segments all longer than broad, filiform, $1^{\text {st }}$ and $2^{\text {nd }}$ anelli transverse, F1 $1.28 \times$ longer than pedicel (45:35) and longer than each of F2-F5 funicular segments, relative measurements: F1 (45:22), F2 (43:22), F3 (37:22), F4 (37:22), F5 (28:22), F6 (28:22); clava about $3.6 \times$ as long as broad and longer than combined length of F5 and F6 (72:61); each funicular segment and 2 basal claval segments at least with 2 to 3 sparse rows of placoid sensilla.

Mesosoma. Dorsally coarsely reticulate, with long white setae, mediodorsally with larger reticulation; in dorsal view $1.4 \times$ as long as broad (200:140) (Fig. 15D), mesosomal length: 200, width: 140, height: 125. Pronotum $2.55 \times$ as broad as long; mesoscutum slightly longer than broad (148:140); mesosoma $1.6 \times$ longer than high (200: 125). Notauli incomplete and not reaching posterior margin of mesoscutum, reaching about middle of mesoscutum, with finer reticulations on lateral lobes of mesoscutum. Scutellum slightly longer than wide (70:65), moderately convex, rounded posteriorly, slightly shorter than mesoscutum (55:58), frenulum distinct. Propodeum (Fig. 16A, E) $0.5 \times$ as long as scutellum (26:55), inclined, finely reticulate, with distinctly raised median carina, forking to an inverted Y-shape carina delimiting nucha, with distinct costula, base of propodeum submedially with two small depressions, enclosed with distinct carinae; spiracle oval and separated from metanotum by its lesser diameter. 


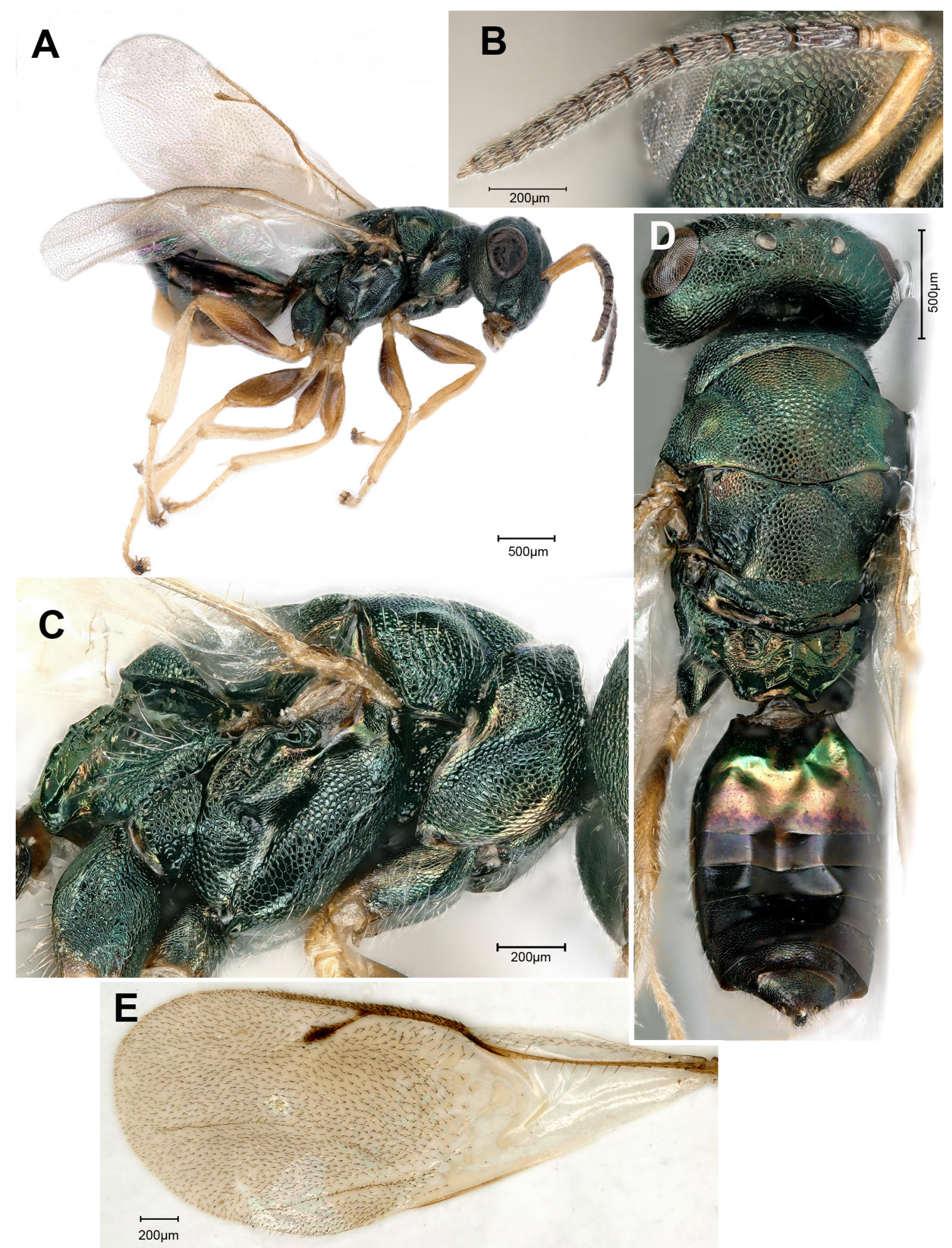

Fig. 15. Stenomalina delvarei Lotfalizadeh \& Rasplus sp. nov. A-C. Holotype, o (HMIM). A. Lateral view. B. Antenna. C. Mesosoma in lateral view. D-E. Paratype, ô (HMIM). D. Dorsal view. E. Fore wing. 
Fore WING (Fig. 2D). Length $2.45 \times$ its width (275:112); costal cell ventrally with three rows of short setae near dorsal margin; basal third of wing bare, basal cell bare and open below; speculum narrow and unconspicuous, open below; disc covered with short and dense pilosity. Relative measurements: costal cell: 105: M: 40; S: 30; PM: 45.

GASTER (Fig. 15D). Lanceolate, dorsally in some parts slightly reticulate, except for GT2-GT4 which is mainly smooth, $1.7 \times$ as long as broad (170:100), shorter than head plus mesosoma (170:204); hind margin of GT1 straight, GT1 is the larger tergite, ca $0.4 \times$ metasoma length (GT1: 70); hind margins of GT2 and GT3 straight. Ovipositor sheaths short, concealed or only very slightly exerted in dorsal view (Fig. 52).

\section{Male}

Similar to female except for following: dody length $3.4 \mathrm{~mm}$; head and mesosoma with golden reflections (Fig. 16C); F1-2 yellowish ventrally (Fig. 16D). Propodeum (Fig. 16E) with less raised carinae beside submedian depressions.

\section{Variation}

Body length of females based on available specimens varies from 3.85 to $4.07 \mathrm{~mm}$.

\section{Biological association}

Host unknown. This species was reared from Phragmites australis in northwest Iran. Species of Chloropidae are its most likely host.

\section{Distribution}

Only known from Iran.

\section{Remarks}

The female is closely related to females of Stenomalina rossiliensis Graham, 1986 and S. liparae (Giraud, 1863) also reared from Phragmites australis, and may be separated by the following key:

\section{Key to species of Stenomalina associated with Phragmites australis}

1. Metasoma short, $1.7 \times$ as long as broad; antenna short, pedicel + flagellum $0.9 \times$ as long as head width Stenomalina delvarei Lotfalizadeh \& Rasplus sp. nov.

- Metasoma long, more than $2.5 \times$ as long as broad; antenna long, pedicel + flagellum distinctly longer than head width (more than $1.2 \times$ )

2. Funicular segments longer than wide (about 1.3-1.5×), excepted F6 quadrate or very slightly elongate Stenomalina liparae (Giraud, 1863)

- All funicular segments longer than wide (about 1.5-2.1×), F6 about 1.5 $\times$ as long as wide

Stenomalina rossiliensis Graham, 1986

Stenomalina delvarei Lotfalizadeh \& Rasplus sp. nov. shares the following characters with S. rossiliensis: elongate funicular segments (more than $1.3 \times$ as long as wide) and the sculpture of the propodeum, with an inverted Y-shaped median carina. Considering some morphological characters mentioned by Graham \& Claridge (1965), this species is similar to Stenomalina liparae and shares the following characters: malar space slightly more than $1 / 2$ as long as eye; elongate funicular segments; temple converging slightly behind the eye dorsally, slightly more than $1 / 3$ as long as eyes; lanceolate metasoma, relatively shorter metasoma (shorter than head + mesosoma). 

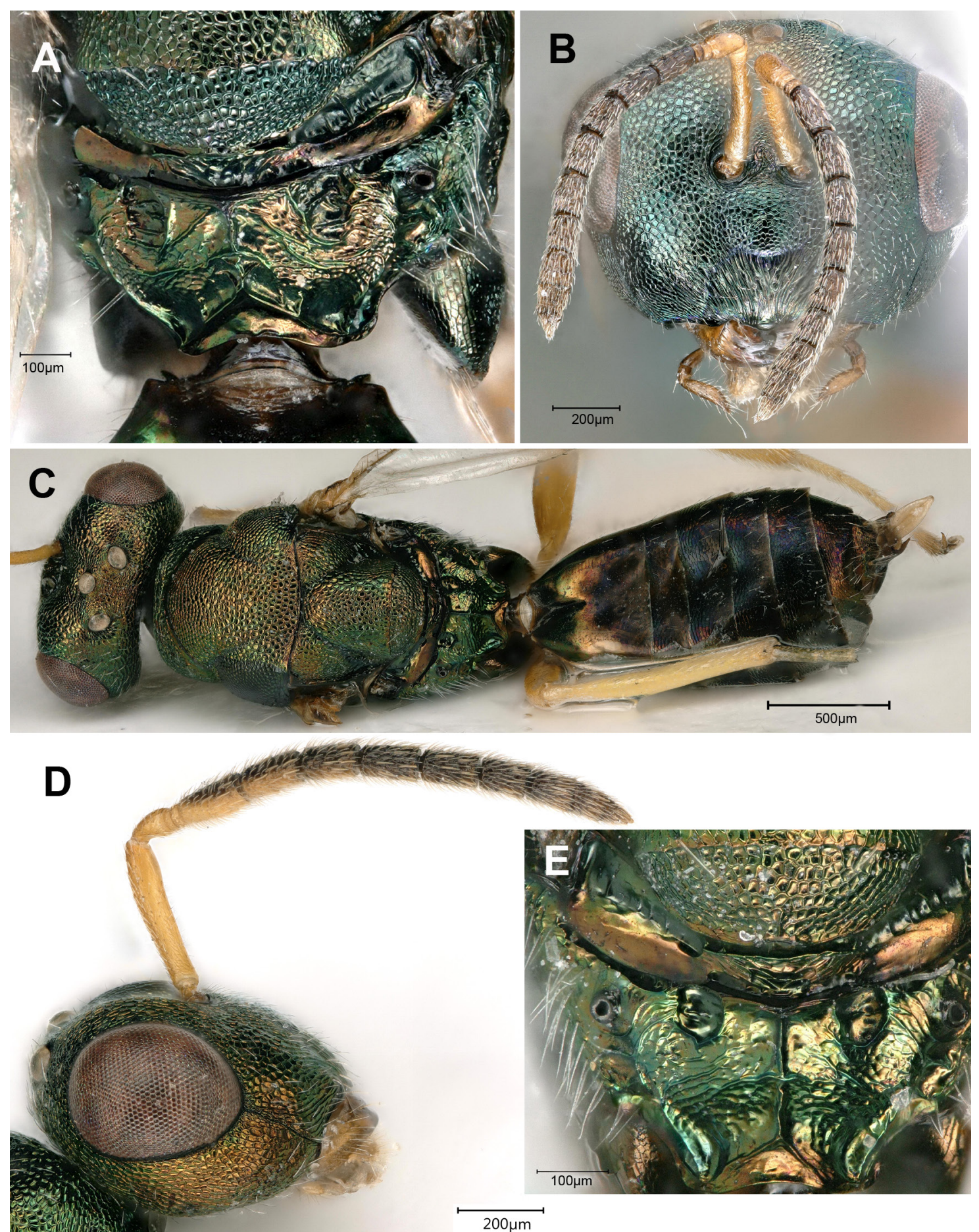

Fig. 16. Stenomalina delvarei Lotfalizadeh \& Rasplus sp. nov. A-B. Holotype, $q$ (HMIM). A. Propodeum in dorsal view. B. Head and antennae in frontal view. C-E. Paratype, $\widehat{\sigma}$ (HMIM). C. Dorsal view. D. Head and antenna in lateral view. E. Propodeum in dorsal view. 
Family Torymidae Walker, 1833

Subfamily Toryminae Walker, 1833

Genus Torymus Dalman, 1820

Torymus arundinis (Walker, 1833)

Fig. 17

\section{Material examined}

IRAN • 2 + ; West-Azarbaijan Province, Urmia, Kelïsä Kandï; $37^{\circ} 29^{\prime}$ N, $45^{\circ} 01^{\prime}$ E; 1600 m a.s.l.; Apr. 2017; Y. Karimpour leg.; ex Phragmites australis; HMIM.

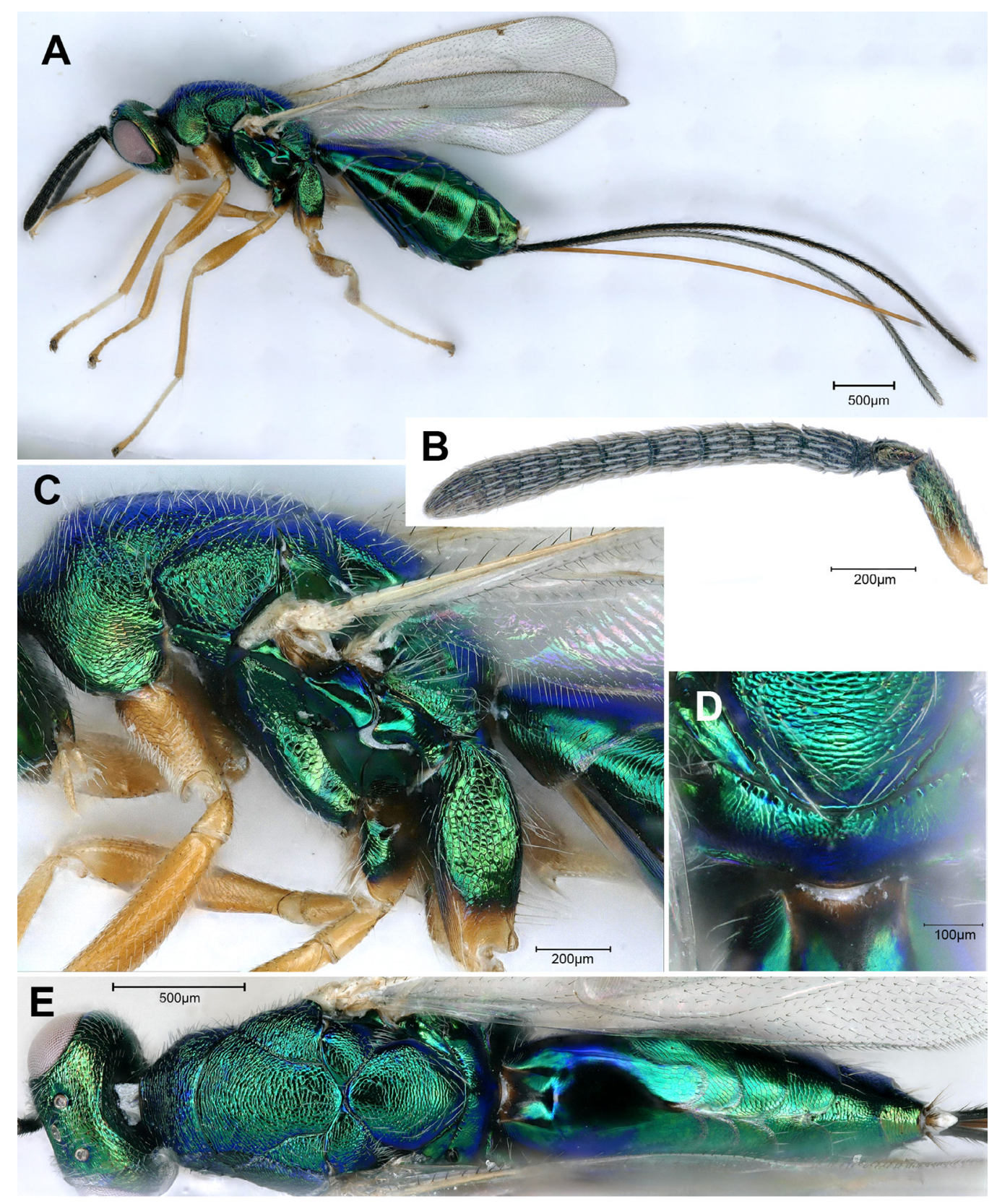

Fig. 17. Torymus arundinis (Walker, 1833). A. Female in lateral view. B. Antenna of female. C. Mesosoma in lateral view. D. Female in dorsal view. 


\section{Remarks}

Torymus arundinis is widely distributed in Europe, but has not yet been reported from the Middle East (Noyes 2020), our specimens represent a new record for Iran. The species may be a parasitoid of Cecidomyiidae (Diptera) on P. australis.

Body length $3.40 \mathrm{~mm}$ (including ovipositor, $7.5 \mathrm{~mm}$ ), ovipositor longer than body (18:15) (Fig. 17A); scape relatively short, not reaching above vertex, all funicular segments longer than wide, F1 longer than F2 (34:30) (Fig. 17B); scutellum without any frenal indication, entirely reticulate, with some piliferous punctures in lateral and dorsal margins (Fig. 17D-E); propodeum (Fig. 17E) with slightly engraved sculpture; hind coxae pilose dorsally in basal half (Fig. 17C); below the cubital line of fore wing with 2-3 rows of setae; metasoma with very long basal sternite, reaching about half the length of the metasoma ventrally.

\section{Discussion}

This is the first effort to study Chalcidoidea associated with $P$. australis in Iran. It revealed the presence of 14 species in five different families, of which two newly reared parasitoids, $N$. persicus Lotfalizadeh \& Rasplus sp. nov. and $S$. delvarei Lotfalizadeh \& Rasplus sp. nov., were described. However, the genera Aximopsis, Echthroplexiella, Homoporus and Neococcidencyrtus were added to former known listed Chalcidoidea on P. australis (Table 1), with the following species A. deserticola, E. obscura, $H$. febriculosus and $N$. poutiersi. Including these new findings to the list of Chalcidoidea on P. australis, the updated list reaches up to 67 species of 35 genera.

Furthermore, the family Encyrtidae with the maximum presence of species (4 spp.) revealed that in this area their hosts (mostly Hemiptera) could be the main pests of P. australis.

Myartseva (1982) reported 13 species of Encyrtidae in Turkmenistan. Based on the present study, only $21 \%$ of obtained chalcidoids (two species of Tetramesa) are the pest of $P$. australis and the rest are parasitoids of other insects Therefore, supplementary investigations are highly advised to reveal the biological association of these parasitoids with supposed insect pests of the families Agromyzidae, Chloropidae, Crambidae, Cecidomyiidae, Mordellidae and Pseudococcidae.

Within the identified species, Aprostocetus orithyia and Norbanus persicus Lotfalizadeh \& Rasplus sp. nov. were the most abundant, that may be parasitoids of Cecidomyiidae and Crambidae, respectively. Finally, the species which have been introduced in this study were collected and identified from a limited area in northwestern Iran. Iran is very diverse in terms of climatic conditions and topography, and the reed plant is spread in many areas of country. Given this diversity, there is no doubt that herbivorous insects associated with reeds and their parasitoids have a considerable diversity throughout Iran, and further studies in different parts of Iran will lead to further identifications of new species and new records as well.

\section{Acknowledgments}

The authors would like to thank M.D. Mitroiu (Faculty of Biology, Alexandru Ioan Cuza University of Iaşi, Romania) for confirming the identity of the new species, two unknown reviewers for reading and making some valuable comments on the manuscript.

\section{References}

Anonymous 2006. National Gazetteer of the Province of Äzarbäijän-e Gharbï (Orümïyeh Township). National Geographical Organization Publication. 
Ashmead W.H. 1904. Classification of the chalcid flies of the superfamily Chalcidoidea, with descriptions of new species in the Carnegie Museum, collected in South America by Herbert H. Smith. Memoirs of the Carnegie Museum 1 (4): 225-551. https://doi.org/10.5962/bhl.title.10341

Askew R.R. 1970. Encyrtidae (Hym., Chalcidoidea) new to Britain. Entomologist 103: 263-264.

Barczak T., Bennewicz J. \& Kaminski P. 2013. Parasitoids (Hymenoptera: Braconidae, Aphidiinae) of the mealy plum aphid Hyalopterus pruni (Geoffr.) on common reed (Phragmites australis) in different type of habitat in Poland. Archives of Biological Sciences, Belgrade 65 (1): 71-79. https://doi.org/10.2298/abs1301071b

Bouček Z. 1968. Contributions to the Czechoslovak fauna of Chalcidoidea (Hym.). Acta Faunistica Entomologica Musei Nationalis Pragae 12: 231-260.

Bouček Z. \& Rasplus J.-Y. 1991. Illustrated Key to West-Palearctic Genera of Pteromalidae (Hymenoptera - Chalcidoidea). INRA Editions, Série Techniques et Pratiques, Paris.

Claridge M.F. 1958. The British and Scandinavian species of the genus Cheiloneurus Westwood (Hym., Encyrtidae). The Entomologist's Monthly Magazine 94: 156-161.

Claridge M.F. 1961. A contribution to the biology and taxonomy of some Palaearctic species of Tetramesa Walker (=Isosoma Walk.; =Harmolita Motsch.) (Hymenoptera: Eurytomidae) with particular reference to the British fauna. Transactions of the Royal Entomological Society of London 113: 175-216. https://doi.org/10.1111/j.1365-2311.1961.tb00807.x

Clevering O. \& Lissner J. 1999. Taxonomy, chromosome numbers, clonal diversity and population dynamics of Phragmites australis. Aquatic Botany 64 (3-4): 185-208.

https://doi.org/10.1016/S0304-3770(99)00059-5

Fallahzadeh M. \& Japoshvili G. 2010. Checklist of Iranian encyrtids (Hymenoptera: Chalcidoidea) with descriptions of new species. Journal of Insect Science 10: 1-24. https://doi.org/10.1673/031.010.6801

Fallahzadeh M., Shojaei M., Ostovan H. \& Kamali K. 2006. The first report of two parasitoid wasps on the larvae of Nephus bipunctatus (Col.: Coccinellidae) from Iran. Journal of Entomological Society of Iran 26 (1): 95-96.

Ferrière C. 1955. Les parasites de la Cochenille des roseaux dans le midi de la France. Bulletin de la Société entomologique de France 60: 8-15.

Gahan A.B. 1933. The serphoid and chalcidoid parasites of the Hessian fly. United States Department of Agriculture Miscellaneous Publication 174: 1-147. https://doi.org/10.5962/bhl.title.65338

Gibson G.A.P. \& Fusu L. 2016. Revision of the Palaearctic species of Eupelmus (Eupelmus) Dalman (Hymenoptera: Chalcidoidea: Eupelmidae). Zootaxa 4081 (1): 1-331.

https://doi.org/10.11646/zootaxa.4081.1.1

Graham M.W.R. de V. 1987. Areclassification of the European Tetrastichinae(Hymenoptera: Eulophidae), with a revision of certain genera. Bulletin of the British Museum (Natural History) 55: 1-392.

Graham, M.W.R. de V. \& Claridge, M.F. 1965. Studies on the Stenomalina-group of Pteromalidae (Hymenoptera: Chalcidoidea). Transactions of the Royal Entomological Society of London 117 (9): 2-11. https://doi.org/10.1111/j.1365-2311.1965.tb00053.x

Graham M.W.R. de V. \& Gijswijt M.J. 1998. Revision of the European species of Torymus Dalman (s. lat.) (Hymenoptera: Torymidae). Zoologische Verhandelingen, Leiden 317: 1-202.

Guerrieri E. 1989. Descrizione del maschio di Asitus phragmitis (Ferrière) (Hymenoptera: Encyrtidae), parasitoids di Chaetococcus phragmitis (Mar.) (Homoptera: Pseudococcidae). Bollettino del Laboratorio di entomologia agraria Filippo Silvestri 46: 157-162. 
Haslam S.M. 1972. Biological flora of the British Isles No. 128: Phragmites communis Trin. Journal of Ecology 60: 585-610.

Japoshvili G. 2012. New data on encyrtid (Hymenoptera: Chalcidoidea: Encyrtidae) parasitoids of coccoids (Hemiptera: Coccoidea) from Turkey, with description of five new species. Entomologica Fennica 23 (2): 72-82. https://doi.org/10.33338/ef.6778

Kalina, V. 1989. Checklist of Czechoslovak Insects III (Hymenoptera). Chalcidoidea. Acta Faunistica Entomologica Musei Nationalis Pragae 19: 97-127.

Kiviat E. 2013. Ecosystem services of Phragmites in North America with emphasis on habitat functions. AoB PLANTS 5: plt008. https://doi.org/10.1093/aobpla/plt008

Lotfalizadeh H. 2015. Review of the Iranian Pteromalinae with speculated antennae, and description of a new species of Norbanus Walker (Hymenoptera: Chalcidoidea, Pteromalidae). Zootaxa 4013 (3): 428-434. https://doi.org/10.11646/zootaxa.4013.3.6

Lotfalizadeh H., Delvare G. \& Rasplus J.-Y. 2007. Phylogenetic analysis of Eurytominae (Chalcidoidea: Eurytomidae) based on morphological characters. Zoological Journal of the Linnean Society 151: 441510. https://doi.org/10.1111/j.1096-3642.2007.00308.x

Mal T.K. \& Narine L. 2004. The biology of Canadian weeds. 129. Phragmites australis (Cav.) Trin, ex Steud. Canadian Journal of Plant Science 84: 365-396. https://doi.org/10.4141/P01-172

Mitroiu M.D. 2015. Revision of the Afrotropical species of Norbanus Walker (Hymenoptera: Pteromalidae). Zootaxa 3969 (1): 1-103. https://doi.org/10.11646/zootaxa.3969.1

Myartseva S.N. 1982. New data on encyrtids (Hymenoptera, Encyrtidae) - parasites of scale insects (Homoptera, Coccoidea) living on Phragmites australis (Cav.). Entomologicheskoe Obozrenie 61 (1): $156-158$.

Noyes J.S. 1987. A review of the species of Neococcidencyrtus (Hymenoptera: Encyrtidae), parasites of diaspidid scale insects. Journal of Natural History 21: 995-1019.

https://doi.org/10.1080/00222938700770611

Noyes J.S. 2020. Universal Chalcidoidea Database. Natural History Museum, London. Available from https://www.nhm.ac.uk/our-science/data/chalcidoids/database/ [accessed 1 Jan. 2020].

Poonawala I.S., Jana M.M. \& Nadgauda R.S. 1999. Factors influencing bud break and rooting and mass scale micropropagation of three Phragmites species: P. karka, P. communis and P. australis. Plant Cell Reports 18: 696-700. https://doi.org/10.1007/s002990050645

Rizzo M.C. \& Mitroiu M.-D. 2010. Revision of the European, North-African and Central Asian species of the genus Norbanus Walker, 1843 (Hymenoptera: Pteromalidae). Journal of Hymenoptera Research 19 (2): $228-243$.

Schwarzländer M. \& Häfliger P. 1999. Evaluating the Potential for Biological Control of Phragmites australis (Cav.) Trin. ex Steudel. Annual Report. CABI Bioscience Centre Switzerland, Delémont, Switzerland.

Srivastava J., Swinder J.S.K. \& Naraian R. 2013. Environmental perspectives of Phragmites australis (Cav.) Trin. ex. Steudel. Applied Water Science 4: 193-202. https://doi.org/10.1007/s13201-013-0142-x

Tewksbury L., Casagrande R., Blossey B., Häfliger P. \& Schwarzländer M. 2002. Potential for biological control of Phragmites australis in North America. Biological Control 23: 191-212.

https://doi.org/10.1006/bcon.2001.0994

Trjapitzin V.A. 1989. Parasitic Hymenoptera of the Fam. Encyrtidae of Palaearctics. Opredeliteli po Faune SSSR 158: 1-489. 
Trjapitzin V.A. 2006. A review of the encyrtid genus Echthroplexiella Mercet, 1921 (Hymenoptera, Encyrtidae) of the World with description of a new species from Mexico. Entomological Review 86: 851-860. https://doi.org/10.1134/S0013873806070086

Tscharntke T. 1999. Insects on common reed (Phragmites australis): community structure and the impact of herbivory on shoot growth. Aquatic Botany 64 (3-4): 399-410.

https://doi.org/10.1016/S0304-3770(99)00066-2

Walker F. 1843. Description des Chalcidites trouvées au Bluff de Saint-Jean, dans la Florida orientale, par MM. E. Doubleday et R. Forster. Annales de la Société entomologique de France (2) 1: 145-162

Zerova M.D. 1976. Hymenoptera. Part 6. Family Eurytomidae; Subfamilies Rileyinae and Harmolitinae. Fauna SSSR. Vol. 110. Academy of Science of the USSR, Zoological Institute, St. Petersburg.

Zerova M.D. 1978. Hymenoptera II. Chalcidoidea 8. Eurytomidae. Opredeliteli Nasekomykh Evropeyskoy Chasti SSR 3: 328-358.

Zerova M.D. 2010. Palaearctic species of the genus Eurytoma (Hymenoptera, Chalcidoidea, Eurytomidae): morphological and biological peculiarities, trophic associations and key to determination. Vestnik Zoologii Supplement 24: 1-203.

Zerova M.D. \& Fursov V.N. 2016. Redescription and new data on the distribution of Tetramesa phragmitis (Hymenoptera, Eurytomidae). Vestnik Zoologii 50 (1): 85-88.

https://doi.org/10.1515/vzoo-2016-0010

Zerova M.D. \& Seryogina L.Y. 2006. Review of the Palaearctic species of the genus Eurytoma, belonging to the E. robusta species-group (Hymenoptera, Eurytomidae), with description of two new species. Entomological Review 86 (6): 695-705. https://doi.org/10.1134/S001387380606008X

Manuscript received: 29 February 2020

Manuscript accepted: 15 July 2020

Published on: 28 August 2020

Topic editor: Gavin Broad

Desk editor: Pepe Fernández

Printed versions of all papers are also deposited in the libraries of the institutes that are members of the EJT consortium: Muséum national d'histoire naturelle, Paris, France; Meise Botanic Garden, Belgium; Royal Museum for Central Africa, Tervuren, Belgium; Royal Belgian Institute of Natural Sciences, Brussels, Belgium; Natural History Museum of Denmark, Copenhagen, Denmark; Naturalis Biodiversity Center, Leiden, the Netherlands; Museo Nacional de Ciencias Naturales-CSIC, Madrid, Spain; Real Jardín Botánico de Madrid CSIC, Spain; Zoological Research Museum Alexander Koenig, Bonn, Germany; National Museum, Prague, Czech Republic. 
Appendix. Updated key to species of the genus Norbanus Walker, 1843 in the Palaearctic region (female \& male) (modified after Rizzo \& Mitroiu 2010). For asterisked figures (*), see Rizzo \& Mitroiu (2010).

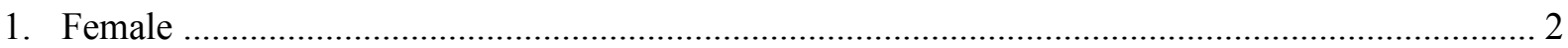

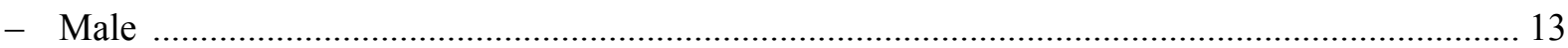

2. Hind margin of first tergite straight or slightly convex in posterior part (fig. $1^{*}$ ) ........................... 3

- Hind margin of first tergite three-lobed (fig. $2^{*}$ ) ............................................................................ 8

3. Fore wing with basal cell and basal vein entirely bare; postmarginal vein shorter than marginal vein (fig. $3^{*}$ )

- Fore wing with basal cell moderately to extensively pilose or, at least, with basal vein pilose; postmarginal vein at least as long as (but often clearly longer than) marginal vein (fig. $5^{*}$ ) ............ 5

4. Antennal funicular segments short, with F1 about $2 \times$ as long as broad; clypeus dorsally reticulate generally; small species, less than $2 \mathrm{~mm}$; metasoma with metallic blue reflections; all body metallic blue

N. tenuicornis Bouček, 1970

- Antennal funicular segments long, with F1 about $3.7 \times$ as long as broad; clypeus dorsally strigose; large species, more than $2 \mathrm{~mm}$; metasoma non-metallic, brown or whitish-yellow; body metallic green, gaster without metallic reflections N. persicus Lotfalizadeh \& Rasplus sp. nov.

5. Basal cell uniformly hairy (fig. $4^{*}$ ); antennal club before spicula either gradually becoming pointed or globose

- Basal cell completely bare or at most pilose in its distal half (figs $5^{*}-6^{*}$ ); antennal club before spicula always gradually becoming pointed, never globose

6. Speculum present; antenna slender with all segments longer than wide, gradually becoming shorter towards antennal apex; club two-segmented, globose, ending with a thin spicula (fig. 22*); head transverse in dorsal view (fig. 13*)

N. meridionalis (Masi, 1922)

- Speculum absent; antenna short, thickening towards apex, with segments from $3^{\text {rd }}$ to $6^{\text {th }}$ subquadrate; club in appearance unisegmented with segments fused; club pointed bearing a short stocky spicula (fig. 19*); head globose in dorsal view with large rounded temples (fig. $7^{*}$ )

N. brevicornis Szelényi, 1974

7. Basal cell: few setae present on the basal vein and sometimes near it (fig. $5^{*}$ ); head strongly transverse in dorsal view, with eyes in lateral position and temples receding, POL $\leq$ OOL (fig. 9*)

N. scabriculus (Nees, 1834)

- Basal cell hairy on the entire distal half (fig. $6^{*}$ ); head transverse but temples present and eyes in antero-lateral position; $\mathrm{POL} \geq \mathrm{OOL}$ (fig. $10^{*}$ )

N. globulariae (Szelényi, 1941)

8. Gaster very long and narrow, more than 4 times as long as broad and about twice as long as head plus mesosoma together, orange with distal third black; very large species (more than $10 \mathrm{~mm}$ )

N. guyoni (Giraud, 1870)

- Gaster much shorter and broader, at most about 3 times as long as broad and not much longer than head plus mesosoma together (fig. $8^{*}$ ), smaller species (up to $7 \mathrm{~mm}$ but usually less)

9. Gena with strongly developed quadrangular lamina at base of mandible (fig. $16^{*}$ )

N. calabrus (Masi, 1942)

- Gena with at most slightly developed rounded lamina at base of mandible (fig. 15*) 10 
10. Sculpture of head and mesosoma very shallow, effaced

N. laevis (Bouček, 1969)

- Sculpture of head and mesosoma deep, not effaced

11. Antenna without an obvious spicula (cf. fig. $17^{*}$ ), dark, proximal part of flagellum broader than pedicel; head in dorsal view about $2.1-2.2 \times$ as wide as long and slightly wider than high in frontal view; head bluish-black, mesosoma bluish, eyes reddish; gaster at most with basal half orange ......

N. cerasiops (Masi, 1922)

- Antenna with distinct spicula (fig. $20^{*}$ ), yellowish, proximal part of flagellum about as broad as pedicel; head in dorsal view more than $2.3 \times$ as wide as long and slightly higher than wide in frontal view; head and mesosoma coppery-green to blackish, eyes brownish; gaster anteriorly without any reddish-orange coloration

12. Antenna darker towards pedicel; gaster brownish; head in dorsal view about $2.5 \times$ as wide as long

N. obscurus (Masi, 1922)

- Antenna lighter towards pedicel (scape, pedicel and $1^{\text {st }}$ anellus yellow), F6 and clava slightly darker than the rest of funicle; gaster reddish-brown in its median part, with metallic greenish-blue reflections distally; head in dorsal view, shorter, $2.3 \times$ as wide as long

N. rasplusi Lotfalizadeh, 2015

13. Hind margin of first tergite straight or slightly convex in posterior part 14

- Hind margin of first tergite three-lobed 18

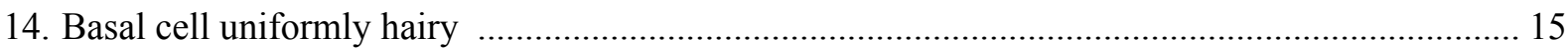

- Basal cell completely bare or at most pilose in its distal half ...................................................... 16

15. Speculum present; head transverse in dorsal view (fig. $11^{*}$ ); antenna with pedicellate funicular segments with whorls of setae (fig. 18*)

N. meridionalis (Masi, 1922)

- Speculum absent; head globose in dorsal view with large rounded temples; antenna with wider segments, covered by very dense short setae

N. brevicornis Szelényi, 1974

16. Funicular segments long and not pedicellate (Figs 12C, 14B)

- Funicular segments pedicellate

N. persicus Lotfalizadeh \& Rasplus sp. nov

17. Basal cell: few setae present on the basal vein and sometimes near it; head strongly transverse in dorsal view, with eyes in lateral position and temples receding, $\mathrm{POL} \leq \mathrm{OOL}$

N. scabriculus (Nees, 1834)

- Basal cell hairy on the entire distal half; head transverse, but temples present and eyes in anterolateral position; $\mathrm{POL} \geq \mathrm{OOL}$

N. globulariae (Szelényi, 1941)

18. Gaster mostly orange; antenna with pedicellate funicular segments with whorls of setae

- Gaster blackish, at most slightly paler basally; antenna with wide segments, covered by very dense short setae

19. Base of gaster, next to petiole, orange, only tip black; antenna shorter, pedicellus plus flagellum only about 1.2 times as long as width of head; tibia entirely yellow

N. guyoni (Giraud, 1870)

- Both base and tip of gaster black; antenna longer, pedicellus plus flagellum 1.5 times as long as width of head; tibia infuscated medially calabrus (Masi, 1942) 
20. Antenna with pedicellus plus flagellum shorter than head width; head about 2.1-2.2 as broad as long in dorsal view (fig. 12*); head bluish-black, mesosoma bluish, eyes reddish

N. cerasiops (Masi, 1922)

- Antenna with pedicellus plus flagellum longer than head width (fig. $21^{*}$ ); head about 1.9 as broad as long in dorsal view (fig. 14*); head and mesosoma dark green, eyes brownish

21. Funicular segments long and with uniform width; metasoma uniformly blackish

N. obscurus (Masi, 1922)

- Funicular segments pedicellate; metasoma not uniformly blackish, with whitish or yellowish marks

22. Funicular segments with two whorls of long setae and few sensillae (1-2); metasoma brownish-black, with distinct metallic reflections, except extensively whitish to yellowish dorsally and ventrally in proximal half or slightly less

N. tenuicornis Bouček, 1970

- Funicular segments with several whorls of long setae and with several sensillae in two rows; metasoma whitish-yellow with its tip and extreme base black, without metallic reflection

N. rasplusi Lotfalizadeh, 2015 